\title{
Analyzing the causes and spatial pattern of the European 2003 carbon flux anomaly using seven models
}

\author{
M. Vetter ${ }^{1}$, G. Churkina ${ }^{1}$, M. Jung ${ }^{1}$, M. Reichstein ${ }^{1}$, S. Zaehle ${ }^{2,3}$, A. Bondeau ${ }^{2}$, Y. Chen ${ }^{1}$, P. Ciais ${ }^{3}$, F. Feser ${ }^{8}$, \\ A. Freibauer ${ }^{1}$, R. Geyer ${ }^{5}$, C. Jones ${ }^{6}$, D. Papale ${ }^{4}$, J. Tenhunen ${ }^{5}$, E. Tomelleri ${ }^{1,7}$, K. Trusilova ${ }^{1}$, N. Viovy ${ }^{3}$, and \\ M. Heimann ${ }^{1}$ \\ ${ }^{1}$ Max-Planck Institute for Biogeochemistry, Hans-Knöll Strasse 10, D-07745 JENA, Germany \\ ${ }^{2}$ Potsdam Institute for Climate Impact Research (PIK), Telegrafenberg A 31, 14473 Potsdam, Germany \\ ${ }^{3}$ Laboratoire des Sciences du Climat et de l'Environnement (LSCE), CEA-CNRS, F-91191 Gif sur Yvette, France \\ ${ }^{4}$ DISAFRI, University of Tuscia, 01100 Viterbo, Italy \\ ${ }^{5}$ Department of Plant Ecology, University of Bayreuth, 95440 Bayreuth, Germany \\ ${ }^{6}$ Hadley Centre, Met Office, Exeter, UK \\ ${ }^{7}$ Centro di Ecologia Alpina (CEALP), Trento, Italy \\ ${ }^{8}$ GKSS-Research Centre, Institute for Coastal Research, Max-Planck-Straße 1, D-21502 Geesthacht, Germany
}

Received: 15 March 2007 - Published in Biogeosciences Discuss.: 19 April 2007

Revised: 27 February 2008 - Accepted: 23 March 2008 - Published: 11 April 2008

\begin{abstract}
Globally, the year 2003 is associated with one of the largest atmospheric $\mathrm{CO}_{2}$ rises on record. In the same year, Europe experienced an anomalously strong flux of $\mathrm{CO}_{2}$ from the land to the atmosphere associated with an exceptionally dry and hot summer in Western and Central Europe. In this study we analyze the magnitude of this carbon flux anomaly and key driving ecosystem processes using simulations of seven terrestrial ecosystem models of different complexity and types (process-oriented and diagnostic). We address the following questions: (1) how large were deviations in the net European carbon flux in 2003 relative to a shortterm baseline (1998-2002) and to longer-term variations in annual fluxes (1980 to 2005), (2) which European regions exhibited the largest changes in carbon fluxes during the growing season 2003, and (3) which ecosystem processes controlled the carbon balance anomaly .

In most models the prominence of 2003 anomaly in carbon fluxes declined with lengthening of the reference period from one year to 16 years. The 2003 anomaly for annual net carbon fluxes ranged between 0.35 and $-0.63 \mathrm{Pg} \mathrm{C}$ for a reference period of one year and between 0.17 and $-0.37 \mathrm{Pg} \mathrm{C}$ for a reference period of 16 years for the whole Europe.

In Western and Central Europe, the anomaly in simulated net ecosystem productivity (NEP) over the growing season in 2003 was outside the $1 \sigma$ variance bound of the carbon flux anomalies for 1980-2005 in all models. The estimated anomaly in net carbon flux ranged between -42 and $-158 \mathrm{Tg}$
\end{abstract}

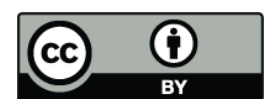

Correspondence to: $\mathrm{M}$. Vetter (mvetter@bgc-jena.mpg.de)
C for Western Europe and between 24 and $-129 \mathrm{Tg} \mathrm{C}$ for Central Europe depending on the model used. All models responded to a dipole pattern of the climate anomaly in 2003. In Western and Central Europe NEP was reduced due to heat and drought. In contrast, lower than normal temperatures and higher air humidity decreased NEP over Northeastern Europe. While models agree on the sign of changes in simulated NEP and gross primary productivity in 2003 over Western and Central Europe, models diverge in the estimates of anomalies in ecosystem respiration. Except for two process models which simulate respiration increase, most models simulated a decrease in ecosystem respiration in 2003. The diagnostic models showed a weaker decrease in ecosystem respiration than the process-oriented models.

Based on the multi-model simulations we estimated the total carbon flux anomaly over the 2003 growing season in Europe to range between -0.02 and $-0.27 \mathrm{Pg} \mathrm{C}$ relative to the net carbon flux in 1998-2002.

\section{Introduction}

Globally, the year 2003 is associated with one of the largest atmospheric $\mathrm{CO}_{2}$ rises on record (Jones and Cox, 2005). This was particularly significant as there was no accompanying large El Nino event that is normally the case in years with high $\mathrm{CO}_{2}$ increase. Drought periods in mid-latitudes of the northern Hemisphere were suggested to cause additional carbon release to the atmosphere large enough to modify dominant ENSO responses in 1998-2002 (Zeng et al. 2005). During these years, atmospheric model inversions have indicated

Published by Copernicus Publications on behalf of the European Geosciences Union. 
that the Northern Hemisphere mid-latitudes went from being a sink ( $0.7 \mathrm{Pg} \mathrm{C} \mathrm{yr-1)}$ to being close to neutral. As terrestrial ecosystems seem to respond to drought with an increased carbon flux to the atmosphere, frequent drought may lead to a faster increase in atmospheric carbon dioxide concentration and accelerate global warming. Thus understanding the response of ecosystems to large-scale drought events is an important issue, particularly given that such drought events are projected to occur more frequently in the future (IPCC 2007; http://www.ipcc.ch/SPM2feb07.pdf). Western and Central Europe experienced extremely hot and dry conditions during the summer of 2003, while Scandinavia, North-Eastern Europe and Russia had lower than normal temperatures and high precipitation (Zveryaev, 2004; Ding and Wang, 2005; Lucero and Rodriguez, 2002; Trigo et al., 2005; Chen at al., in prep.). The Central European "summer drought" caused a decrease in carbon sequestration over large areas (Reichstein et al., 2006, Schindler et al., 2006, Ciais et al., 2005), whereas areas normally experiencing temperature limitation as the Alps, experienced an increase in carbon sequestration (Jolly et al., 2005). Ciais et al. (2005) showed using a single model that the source anomaly was rather caused by a drop in the gross primary production than increased ecosystem respiration resulting in an anomalous net loss of $0.5 \mathrm{Pg}$ of carbon to the atmosphere through July-September 2003 relative to the average carbon flux from 1998-2002. Reichstein et al. (2006) further investigated the 2003 carbon flux anomaly using the results from 4 different models. However, in their study, the model drivers and simulation protocols were not harmonized. Differences among the models could not be completely separated from the effect of different inputs. As a result they could not conduct an in depth analysis of the responses of the component carbon fluxes. They concluded that both gross primary productivity (GPP) and ecosystem respiration (Reco) were reduced in the year 2003.

In this study, we use five process-based terrestrial ecosystem models (TEMs), one remote-sensing driven model and one artificial neural network to analyze European ecosystem responses to climate variations with special emphasis on 2003. All models are driven with the same input data. This allows us to assess the regional significance of the 2003 anomaly in the European carbon balance together with the uncertainty in its estimates caused by different parameterizations and assumptions used in the different models.

We will address the following questions: (1) how large were the anomalies in the regional carbon fluxes during 2003 growing season (May-September) relative to long-term growing season variation, (2) do the models agree on the regions exhibited the largest deviations in carbon fluxes during the growing season 2003, and (3) which processes, photosynthesis or respiration, controlled the carbon balance anomaly in the models.

\section{Methods}

\subsection{Model descriptions}

In this study, we use five process-based terrestrial ecosystem models of different complexity (Biome-BGC, LPJ, ORCHIDEE, JULES and PIXGRO) and two data oriented models (MOD17+ and NETWORK $\mathrm{NNN}_{\mathrm{ANN}}$ ) to simulate carbon fluxes. Except NETWORK $\mathrm{ANN}_{\mathrm{A}}$ all models simulated gross primary productivity and respiration independently. The models also differed by the number of simulated biomes as well as implementation of crop- and crop management. Key features of the models in terms of representing photosynthesis, respiration and the terrestrial water cycle are summarized in Table 1. For a more detailed description of the major processes and the model differences see appendix (Table A1 to A4).

\subsubsection{Biome-BGC}

Biome-BGC is a terrestrial ecosystem model describing the carbon, nitrogen and water cycles (Running and Gower, 1991; Thornton et al., 2002, Table 1). It has been corroborated for a number of hydrological, carbon cycle components and forest management (Cienciala et al., 1998; Churkina and Running, 2000; Churkina et al., 2003; Thornton et al., 2002; Vetter et al., 2005). Biome-BGC is parameterized for seven biomes including evergreen needleleaf (enf), evergreen broadleaf (ebf) (Trusilova et al., in review ${ }^{1}$ ), deciduous needleleaf (dnf), deciduous broadleaf (dbf), shrubs (sh), and grass (C3 and $\mathrm{C} 4$ type photosynthesis) as well as fertilized grasses. The model does not include a special crop phenology, and simulates crops as fertilized grasses with no further management such as harvest. Forest management was not included due to lack of detailed regional inventories of forest age structure.

\subsubsection{Lund-Potsdam-Jena dynamic global vegetation model for managed Land (LPJmL)}

LPJmL is a terrestrial ecosystem model describing the carbon and water cycles of natural, semi-natural and anthropogenic ecosystems (Sitch et al., 2003; Bondeau et al., 2007; Zaehle et al., 2007; Table 1). It includes representations of boreal and temperate evergreen needleleaf (enf), deciduous needleleaf (dnf), deciduous broadleaf (dbf), and evergreen broadleaf tree types (ebf), as well as two grass and $11 \mathrm{crop}$ types. Vegetation dynamics and management are calculated separately for each landcover type. Dynamics of crops' and managed forest were simulated as described by Bondeau et al. (2007) and by Zaehle et al. (2007) accordingly. To be

\footnotetext{
${ }^{1}$ Trusilova, K., Churkina, G., Vetter, M., Reichstein, M., Schumacher, J., Knohl, A., Rannik, U., Gruenewald, T., Moors, E., Granier, A.: Parameter estimation for the terrestrial ecosystem model BIOME-BGC using non linear inversions, in preparation.
} 
Table 1. Detailed description of the major ecosystem processes being simulated by the participating models.

\begin{tabular}{|c|c|c|c|c|c|c|c|}
\hline Model: & Biome-BGC & LPJ & ORCHIDEE & JULES & PIXGRO & MOD17+ & ANN \\
\hline Homepage http:// & & www.pik-potsdam.de/lpj/ & $\begin{array}{l}\text { www.ipsl.jussieu.fr/ } \\
\sim \text { ssipsl/doc/doc_main.html }\end{array}$ & $\begin{array}{l}\text { www.jchmr.org/jules/index. } \\
\text { html }\end{array}$ & & & \\
\hline Photosynthesis & $\begin{array}{l}\text { Photosynthesis of C3 and C4 } \\
\text { plants after De Pury and Far- } \\
\text { quhar (1997), and Woodrow and } \\
\text { Berry (1980), dependent on leaf } \\
\text { nitrogen content }\end{array}$ & $\begin{array}{l}\text { Net Photosynthesis based } \\
\text { on Farquhar's model } \\
\text { simplified by Collatz et } \\
\text { al. (1992) + optimum } \\
\text { canopy distribution of } \\
\text { nitrogen (Haxeltine and } \\
\text { Prentice, 1996) (leaf } \\
\text { respiration is subtracted). }\end{array}$ & $\begin{array}{l}\text { Farquhar et al. (1980) for } \\
\text { C3 plants and Collatz et } \\
\text { al. (1992) for C4 plants }\end{array}$ & $\begin{array}{l}\text { Photosynthesis according to } \\
\text { Collatz et al. (1991) for C3 } \\
\text { and Collatz et al. (1992) C4 }\end{array}$ & $\begin{array}{l}\text { Net Photosyntesis } \\
\text { according to the } \\
\text { methodology in } \\
\text { Owen et al. (2007) } \\
\text { and needs input of } \\
\text { max LAI estimated } \\
\text { from MODIS } \\
\text { (leaf respiration is } \\
\text { subtracted) }\end{array}$ & $\begin{array}{l}\text { Photosynthesis } \\
\text { according to Reich- } \\
\text { stein et al. (2004), } \\
\text { empirical depen- } \\
\text { dency of assimi- } \\
\text { lation to climate } \\
\text { parameters from } \\
\text { CARBOEUROPE } \\
\text { network }\end{array}$ & $\begin{array}{l}\text { Photosyntesis is } \\
\text { simulated with } \\
\text { Artificial Neural } \\
\text { Network, meth- } \\
\text { ods in (Papale } \\
\text { and Valentini, } \\
\text { 2003; Scardi et } \\
\text { al., 2000), trained } \\
\text { with } 62 \text { Carboeu- } \\
\text { ropeIP sites Eddy } \\
\text { covariance data } \\
\text { treated accord- } \\
\text { ing to Papale et } \\
\text { al. (2006); Reich- } \\
\text { stein et al., (2005). } \\
\text { All networks use } \\
\text { a Levenberg - } \\
\text { Marquardt training } \\
\text { algorithm and } \\
\text { transfer functions } \\
\text { see Reichstein et } \\
\text { al. (2006) }\end{array}$ \\
\hline $\begin{array}{l}\text { Stomatal conduc- } \\
\text { tance }\end{array}$ & $\begin{array}{l}\text { Calculated as a dependence on } \\
\text { soil water potential, minimum } \\
\text { temperature, VPD and photon } \\
\text { flux density according to Korner } \\
\text { et al. (1995) }\end{array}$ & $\begin{array}{l}\text { Calculated as a function } \\
\text { of potential photosynthesis } \\
\text { rate and water stress (Hax- } \\
\text { eltine and Prentice, 1996) }\end{array}$ & $\begin{array}{l}\text { Ball et al. (1987) based on } \\
\text { Ball and Berry (Ball et al., } \\
\text { 1982) }\end{array}$ & $\begin{array}{l}\text { Based on Jacobs. (1994) and } \\
\text { Cox et al. (1998, 1999), in- } \\
\text { cluding soil-moisture depen- } \\
\text { dence }\end{array}$ & $\begin{array}{l}\text { Calculated accord- } \\
\text { ing to Ball and } \\
\text { Berry (Ball et al., } \\
\text { 1982) }\end{array}$ & & \\
\hline $\begin{array}{l}\text { Ecosystem respira- } \\
\text { tion (Reco) } \\
\text { Autotrophic respi- } \\
\text { ration (AR) } \\
\text { Heterotrophic res- } \\
\text { piration (HR) }\end{array}$ & $\begin{array}{l}\text { Reco: AR + HR. } \\
\text { AR: Sum of maintenance (MR) } \\
\text { and growth (GR) respiration. } \\
\text { MR: calculated separately for } \\
\text { leaf, stem and roots, dependent } \\
\text { on tissue nitrogen content and } \\
\text { temperature (Ryan, 1991). GR: } \\
\text { calculated for each plant com- } \\
\text { partment as production costs } \\
\text { (30\% per carbon produced) } \\
\text { HR: decomposition of litter and } \\
\text { soil, related to chemical com- } \\
\text { position (cellulose, lignin, hu- } \\
\text { mus), C:N ratios, mineral ni- } \\
\text { trogen availability, soil moisture } \\
\text { (Andren and Paustian, 1987), } \\
\text { Orchard and Cook (1983), and } \\
\text { temperature (Lloyd and Taylor, } \\
\text { 1994) }\end{array}$ & $\begin{array}{l}\text { Reco: AR + HR } \\
\text { AR: sum of maintenance } \\
\text { (MR) and growth (GR) res- } \\
\text { piration. MR: using fixed } \\
\text { C:N ratios following the } \\
\text { method in Ryan (1991) and } \\
\text { Sprugel (1995). GR: pro- } \\
\text { duction costs per carbon } \\
\text { produced (25\%) } \\
\text { HR: based on an empiri- } \\
\text { cal Arrhenius dependence } \\
\text { of temperature (Lloyd and } \\
\text { Taylor, 1994). Decompos- } \\
\text { tion depends on tissue type } \\
\text { and moisture (Foley, 1995) }\end{array}$ & $\begin{array}{l}\text { Reco: AR + HR } \\
\text { AR: sum of maintenance } \\
\text { (MR) and growth (GR) res- } \\
\text { piration. MR: calculated as } \\
\text { a function of temperature, } \\
\text { biomass and fixed C:N ra- } \\
\text { tios. GR: calculated for } \\
\text { each plant compartment as } \\
\text { production costs ( } 28 \% \text { ) } \\
\text { HR: Modified Arrhenius } \\
\text { dependence on temperature } \\
\text { (Lloyd and Taylor, 1994) } \\
\text { Detailed description in } \\
\text { (Krinner et al., 2005; } \\
\text { Viovy, 1996) }\end{array}$ & $\begin{array}{l}\text { Reco: } \mathrm{AR}+\mathrm{HR} \\
\text { AR: sum of maintenance } \\
\text { (MR) and growth (GR) res- } \\
\text { piration. MR: stem and root } \\
\text { dependent on temperature } \\
\text { and mean canopy nitrogen } \\
\text { content proportional to LAI } \\
\text { and canopy height, leaf MR: } \\
\text { additional moisture depen- } \\
\text { dent (Friend, 1993). HR: } \\
\text { soil moisture dependence } \\
\text { according to McGuire et } \\
\text { al. (1992) } \\
\text { Detailed description in Essery } \\
\text { et al. (2003) }\end{array}$ & $\begin{array}{l}\text { Ecosystem respi- } \\
\text { ration based on } \\
\text { Reichstein et al. } \\
(2005) \text { decoupled } \\
\text { from productivity } \\
\text { and dependent on } \\
\text { soil temperature } \\
\text { and soil moisture }\end{array}$ & $\begin{array}{l}\text { Ecosystem res- } \\
\text { piration based } \\
\text { on Reichstein et } \\
\text { al. (2003b), adding } \\
\text { short term depen- } \\
\text { dence on GPP, } \\
\text { adding Arrhenius } \\
\text { type temperature } \\
\text { dependence ac- } \\
\text { cording to methods } \\
\text { in (Reichstein et } \\
\text { al., 2005), added } \\
\text { quasi steady state: } \\
\text { Reco_avg=0.95xGPP } \\
\text { over the period, } \\
\text { Long-term mean } \\
\text { being affected, in- } \\
\text { ter annual variabil- } \\
\text { ity is conserved. }\end{array}$ & $\begin{array}{l}\text { Ecosystem respi- } \\
\text { ration is estimated } \\
\text { as the difference } \\
\text { between NEP, } \\
\text { (-NEE) and GPP, } \\
\text { NEE being sim- } \\
\text { ulated with the } \\
\text { same methods as } \\
\text { described above for } \\
\text { GPP based on the } \\
62 \text { CarboeuropeIP } \\
\text { sites. }\end{array}$ \\
\hline $\begin{array}{l}\text { Evapo- } \\
\text { transpiration }\end{array}$ & $\begin{array}{l}\text { Computed daily using the } \\
\text { Penman-Monteith combination } \\
\text { equation (Monteith, 1965) }\end{array}$ & $\begin{array}{l}\text { Total evapotranspiration } \\
\text { (Monteith, 1995) }\end{array}$ & $\begin{array}{l}\text { Bulk formula to formulate } \\
\text { surface fluxes (Ducoudre et } \\
\text { al., 1993) }\end{array}$ & $\begin{array}{l}\text { Evaporated from each soil } \\
\text { layer by roots, and soil evao- } \\
\text { poration dependent on soil } \\
\text { moisture and root density } \\
\text { (Richards, 1931) }\end{array}$ & $\begin{array}{l}\text { Evapotranspiration } \\
\text { according to } \\
\text { Reichstein (2001) } \\
\text { and } \\
\begin{array}{l}\text { Reichstein } \\
\text { al. (2003b) }\end{array}\end{array}$ & & \\
\hline Water balance & $\begin{array}{l}\text { Single bucket model: Precipita- } \\
\text { tion balanced with evapotransir- } \\
\text { ation and runoff, snow-pack }\end{array}$ & $\begin{array}{l}\text { Two bucket model adapted } \\
\text { from (Neilson, 1993), } \\
\text { precipitation balanced } \\
\text { with runoff and drainage, } \\
\text { snow-pack }\end{array}$ & $\begin{array}{l}\text { Two bucket model with } \\
\text { variable depth, precip- } \\
\text { itation balanced with } \\
\text { drainage and runoff }\end{array}$ & $\begin{array}{l}\text { Multi-layer soil module based } \\
\text { on Richards (1931), temper- } \\
\text { ature conductivity (Cox et } \\
\text { al., 1999), modified by snow- } \\
\text { pack, hydrology (Gregory and } \\
\text { Smith, 1990) }\end{array}$ & 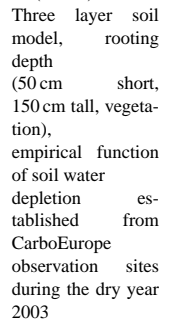 & & \\
\hline Nitrogen dynamics & $\begin{array}{l}\text { Simulated explicit, described in } \\
\text { (Running and Gower, 1991; } \\
\text { Thornton et al., 2002). }\end{array}$ & Not explicitly simulated & Not explicitly simulated & Not explicitly simulated & $\begin{array}{l}\text { Not explicitly sim- } \\
\text { ulated }\end{array}$ & & \\
\hline
\end{tabular}

consistent with the other models in this comparison, neither cropland irrigation nor land-use change was simulated.

\subsubsection{ORCHIDEE}

The ORCHIDEE biosphere model describes the carbon, energy and water fluxes (Krinner et al., 2005; Viovy, 1996; Table 1). ORCHIDEE differentiates between 12 different plant functional types over the globe (7 of significance over Europe), similar to LPJ, of which two are representing crops with C3 and C4-photosynthesis as fertile, harvested grassland. Long-term vegetation dynamics, adapted from the LPJ model (Sitch et al., 2003) are not simulated here for consistency with other models. ORCHIDEE runs with hourly time-steps climate forcing.

\subsubsection{Joint UK Land Environment Simulator (JULES)}

JULES is a land-surface model based on the MOSES2 land surface scheme (Essery et al., 2003) used in the Hadley 
Centre climate model HadGEM (Johns et al., 2006), also incorporating the TRIFFID DGVM (Cox, 2001; Cox et al., 2000, Table 1). The model simulates carbon, water and energy fluxes on 9 sub-grid tiles, including 5 plant functional types: broadleaf and needleleaf trees, $\mathrm{C} 3$ and $\mathrm{C} 4$ grasses and shrubs. In this study JULES is driven by hourly time-steps (see Tables 2 and 3). JULES does not simulate crops and crop management and represent these as natural C3 grasses. Due to technical reasons the model was run with homogenous soil depth of $3 \mathrm{~m}$ everywhere.

\subsubsection{PIXGRO}

PIXGRO is a canopy flux and, in the case of short-stature vegetation (grassland, crops, tundra, or wetlands), growth model for simulation of carbon and water fluxes (Adiku et al., 2006; Reichstein, 2001; Reichstein et al., 2004, Table 1). The model has been applied on landscape to continental scale and regions (Tenhunen et al., 2007²; Tenhunen et al., 2007). In this continental scale study, the single-layered canopy model described in Owen et al. (2007) was applied. Canopy capacity for $\mathrm{CO}_{2}$ uptake is estimated from $\mathrm{CO}_{2}$ flux measurements at the sites of CarboEurope network for conifer and deciduous forests, Mediterranean shrublands, grasslands, tundra and crops. PIXGRO uses remote sensing data from MODIS to establish the max LAI for forests and shrublands of each year. Crops are represented as summer and winter grains, root crops, and maize. Phenology across the continent is based on temperature, principles related to winter dormancy and spring green up as elaborated by Zhang et al. (2004). Crops' harvest is explicitly simulated.

\subsubsection{MOD17+}

MOD17+ is a semi-empirical diagnostic model (Reichstein et al., 2004, 2003b, 2005a, 2005b; Table 1) driven by remotely sensed data. It is based on a radiation-use efficiency model (Nemani et al., 2003), which has been implemented for calculating the operational global MODIS-NPP product at $1 \mathrm{~km}$ resolution (Running et al., 2004).

\subsubsection{NETWORK ANN $_{\text {N }}$}

NETWORK $_{\text {ANN }}$ is a diagnostic modeling approach based on Artificial Neural Networks (ANNs) (Papale and Valentini, 2003; Table 1). ANN was trained with flux measurements covering seven different landcovers: deciduous broadleaf forest (11 sites), evergreen needleleaf forests (15 sites), evergreen broadleaf forests and shrublands (6 sites), grasslands

\footnotetext{
2 Tenhunen, J., Geyer, R., Adiku, S., Tappeiner, U., Bahn, M., Dinh, N.Q., Kolcun, O., Lohila, A., Owen, K., Reichstein, M., Schmidt, M., Wang, Q., Wartinger, M., Wohlfahrt, G., and Cernusca, A.: Influences of landuse change on ecosystem and landscape level carbon and water balances in mountainous terrain of the Stubai Valley, Austria, submitted to Global Planetary Change, 2007.
}

and wetland (18 sites), croplands (12 sites). The datasets used in the ANNs training were divided in three subsets, such as training, test and validation sets. The last one was only used to assess the ANN ability to simulate $\mathrm{CO}_{2}$ flux.

\section{Model inputs}

The climate data were obtained with the regional climate model REMO (REgionalMOdel, Jacob and Podzun, 1997) forced with global 6-hourly NCEP (National Centers for Environmental Prediction) reanalyses (Kalnay et al., 1996) from 1948 until the current time. The major reason for choosing REMO derived climate data as driver for ecosystem model simulations in this study was a combination of its temporal continuity and quality (Chen et al., report). The prognostic variables are surface air pressure, temperature, horizontal wind components, specific humidity and cloud water. The physics scheme applied is a version of the global model ECHAM4 physics of the Max-Planck-Institute for meteorology adapted for the regional model (Koch and Feser, 2006). The model simulation was computed with additional "nudging of large scales" (von Storch et al., 2000). Thereby the simulated state is kept close to the driving state at larger scales, while allowing the model to freely generate regional-scale weather phenomena consistent with the largescale state. A more detailed description of the multi-decadal simulation is given in Feser et al. (2001). The atmospheric hourly values were then interpolated to a regular latitudelongitude grid with a grid spacing of $0.25^{\circ} \times 0.25^{\circ}$ and aggregated to daily and monthly values as needed by the different models (see Table 2, Table 3). The models used the REMO-derived climate from 1958 until 2005.

To include the effect of environmental change on the estimates of the carbon-fluxes over Europe we used the annual values of the $\mathrm{CO}_{2}$ concentrations over the northern Hemisphere. These values were based on ice core data from Etheridge (1996) and atmospheric data from Mauna Loa (Keeling and Whorf, 2005). They cover the time until the end of 2004. The $\mathrm{CO}_{2}$ concentration for the year 2005 was added by using the annual global trend reported by NOAA/CMDL of $2.08 \mathrm{ppm}$ as an average from January 2004-December 2005, (Table 3).

All models used the same maps of elevation above the sea level, soil texture, soil-depth (except JULES, which due to technical reasons, was run with $3 \mathrm{~m}$ soil-depth for all land cells) and land cover classification (Table 3). All models used prescribed land cover types (Jung et al., 2006), which were held constant during the simulations. Biome-BGC is also simulating the nitrogen cycle and requires data on reactive nitrogen deposition. We used the atmospheric nitrogen deposition maps as reported by Galloway et al. (2004). For the spin-up runs we used the maximum pre-industrial constant of $0.0002 \mathrm{~kg} \mathrm{~N} / \mathrm{m} 2 / \mathrm{yr}$ (Holland et al., 1999). The nitrogen fertilizer inputs over agricultural areas were calculated 
Table 2. Overview of the models participating in this study and the temporal resolution of the REMO derived climate-drivers needed. Hourly input (h), daily input (d), and monthly input (m). ORCHIDDE and JULES used different sub-daily resolutions in their simulations.

\begin{tabular}{lllll}
\hline Model & temperature & Precipitation & radiation & humidity \\
\hline TEMs & & & & \\
Biome-BGC & $\mathrm{d}$ & $\mathrm{d}$ & $\mathrm{d}$ & $\mathrm{d}^{*}$ \\
LPJ & $\mathrm{m}$ & $\mathrm{m}$ & $\mathrm{m}$ & $\mathrm{m}$ \\
ORCHIDEE & $\mathrm{h}$ & $\mathrm{h}$ & $\mathrm{h}$ & $\mathrm{h}$ \\
JULES & $\mathrm{h}$ & $\mathrm{h}$ & $\mathrm{h}$ & $\mathrm{h}$ \\
PIXGRO & $\mathrm{h}$ & $\mathrm{h}$ & $\mathrm{h}$ & $\mathrm{h}$ \\
& & Diagnostic models & & \\
MOD17+ & $\mathrm{d}$ & $\mathrm{d}$ & $\mathrm{d}$ & $\mathrm{d}^{*}$ \\
ANN & $\mathrm{d}$ & $\mathrm{d}$ & $\mathrm{d}$ & $\mathrm{d}^{*}$ \\
\hline
\end{tabular}

$* \mathrm{VPD}$

Table 3. Model input data (land surface, climate data, atmospheric $\mathrm{CO}_{2}$ concentration, atmospheric nitrogen deposition and nitrogen fertilization) used by the terrestrial ecosystem models in this study.

\begin{tabular}{|c|c|}
\hline Parameter & Source \\
\hline Albedo & MODIS (MOD43B) (Lucht et al., 2000; Schaaf et al., 2002) \\
\hline Elevation & GTOPO 30; http://edc.usgs.gov/products/elevation/gtopo30/gtopo30.html \\
\hline Soil depth & $\begin{array}{l}\text { TERRASTAT - Global Land Resources GIS Models and Databases, FAO } \\
\text { Land and Water Digital Media Series \# } 20\end{array}$ \\
\hline Soil texture & Global Soil Data Products CD-ROM (IGBP-DIS) \\
\hline $\begin{array}{l}\text { Landcover } \\
\text { Water holding capacity pedo transfer func- } \\
\text { tions }\end{array}$ & $\begin{array}{l}\text { SYNMAP (Jung et al., 2006) } \\
\text { Cosby et al. (1984), Saxton et al. (1986) }\end{array}$ \\
\hline \multicolumn{2}{|l|}{$\begin{array}{l}\text { Temperature } \\
\text { (max,min, daily average) }\end{array}$} \\
\hline $\begin{array}{l}\text { Precipitation } \\
\text { Short wave solar downward radiation } \\
\text { Vapor pressure deficit (VPD) } \\
\text { Relative humidity }\end{array}$ & $\begin{array}{l}\text { REMO Feser et al. (2001), Koch and Feser (2006), } \\
\text { REMO Jacob and Podzun (1997), Kalnay et al. (1997), Storch et al. (2000) }\end{array}$ \\
\hline Atmospheric $\mathrm{CO}_{2}$ concentration & $\begin{array}{l}\text { Etheridge (1996) Keeling and coworkers, as deposited on the ORNL CDIAC } \\
\text { data repository, in } 2004\end{array}$ \\
\hline Atmospheric nitrogen deposition & Galloway (2004), Holland (1999) \\
\hline Nitrogen fertilization & $\begin{array}{l}\text { Freibauer (2003), } \\
\text { http://faostat.fao.org/site/422/default.aspx }\end{array}$ \\
\hline
\end{tabular}

according to Freibauer (2003) and the FAO Statistics June 2006 (http://faostat.fao.org/site/422/default.aspx). We added both mineral nitrogen fertilizer as well as the total of manure and slurry from animal husbandry generating Europe-wide fertilization maps for 1961, 1989 and 2002 for the agricultural areas. The fertilization maps were interpolated between the years to describe the annual changes in fertilizer usage over Europe.

\subsection{Model simulations}

Using the same input drivers all models performed simulations over Europe in the domain bounded by $15^{\circ} \mathrm{W}-60^{\circ} \mathrm{E}$ and $30^{\circ} \mathrm{N}-75^{\circ} \mathrm{N}$. This covers area from Iceland to Ural Mountains and from the Mediterranean Sea to the Barents Sea. Europe has been further divided into four regions (North, West, Central and East; Fig. 1) in order to regionally 


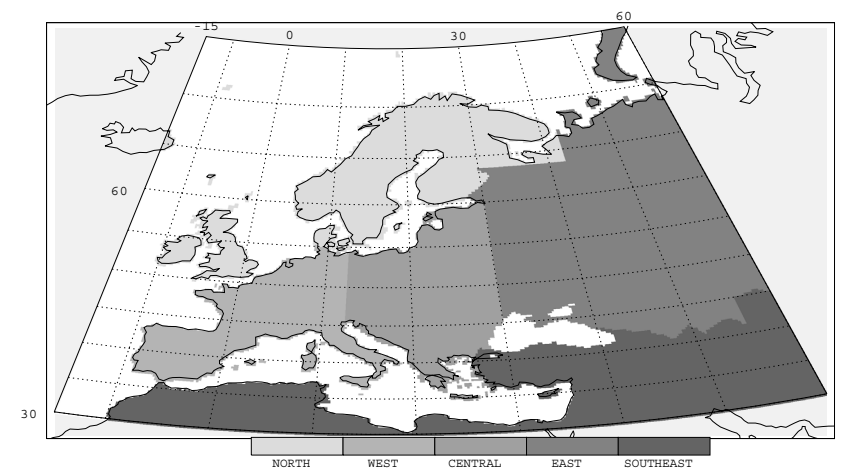

Fig. 1. View of different regions of Europe: Northern Europe, Western Europe, Central Europe, Eastern Europe.

examine the changes in terrestrial $\mathrm{CO}_{2}$ exchange. This simple division to compare model output is arbitrary and does not follows ecosystem or bioclimatic zones boundaries.

The process oriented models which also calculate the carbon pools need to spin-up to initialize slow carbon and nitrogen pools. We forced the models in a pre-industrial steady-state using atmospheric $\mathrm{CO}_{2}$ concentrations (and nitrogen deposition for Biome-BGC) from $\sim 1850$ (285.2 ppm, $0.0002 \mathrm{kgN} / \mathrm{m} 2 / \mathrm{yr}$ ) and recycling one decade of meteorological data (1958-1967) that does not exhibit significant trends of temperature and precipitation change over Europe. After establishing the slow pools, we run the models from 1850 to 1957 with transient atmospheric $\mathrm{CO}_{2}$ using the same decade of meteorological data. The last transient model runs from 1958-2005 use observed $\mathrm{CO}_{2}$ concentrations and corresponding meteorological data from REMO. Although rising $\mathrm{CO}_{2}$ levels are responsible for long term net carbon uptake, interannual variability in these simulations is driven solely by climate variations (Harrison et al., 2008). These final runs are the basis of our analysis.

The diagnostic models were forced with climate divers from the period 2000-2004 since they rely on remotely sensed input data from MODIS (launched in 2000). PIXGRO was run only for 2002 and 2003, because this model is computationally very demanding.

3.2 Analysis of spatial and temporal pattern of the climate and carbon flux anomalies in 2003

Our analysis is based on carbon fluxes simulations from 1980 until 2005. We define the growing season from 1 May to 30 September. The carbon fluxes are summed over this period. The carbon flux anomaly $A_{i, j}$ in 2003 for each grid-cell is calculated as

$A_{j, i}=F_{2003 j, i}-\bar{F}_{1998-2002 j, i}$

where $F_{2003}$ denotes total carbon flux over the growing season 2003 ,

$\bar{F}_{1998-2002}$ denotes the total carbon flux averaged over five growing seasons (1998-2002), j and i are the longitude and latitude respectively. In addition we estimate the change in carbon fluxes between the years 2003 and 2002, for better comparison with other studies of the carbon-flux anomaly in 2003 (Reichstein et al., 2006; Ciais et al., 2005), and for explaining differences in carbon flux responses between PIXGRO and the other models.

For each of the four European regions (Fig. 1) we estimated the carbon flux anomaly for the growing seasons 1980-2005 weighted by area. We used the average length of a growing season from 1998 until 2002 as baseline. We have chosen the period 1998-2002 as a reference for our study because we wanted to compare our results with outcomes from previous studies (Ciais et al., 2005). We use the model results from the period 1980-2005 as the quality of the climate data for this period is unbiased (Chen et al., report). In PIXGRO the calculations of carbon flux anomaly is based only on the years 2002 and 2003.

First, we estimated the anomalies of each growing season (1980-2005) relative to the reference period 1998-2002. Based on these anomalies we then derived the mean anomaly for the growing seasons 1980-2005, as well as the standard deviations, and the median. As the anomalies in carbon fluxes simulated by the models varied in magnitude, we normalized the anomalies by dividing them with the corresponding standard deviations. This normalization procedure forced the standard deviation of the carbon flux anomaly of each model to be one.

The climate anomalies were derived similar to the carbon flux anomalies described above. The climate anomalies included growing season averages for temperature, radiation, vapor pressure deficit (VPD) and water balance. For the precipitation the growing season sums were estimated.

In addition to the growing season anomalies we also derived the annual values of the estimated carbon fluxes and the corresponding annual anomalies.

\section{Results and discussion}

4.1 Regional climate and carbon flux anomalies of the growing season 2003

All models agree in the negative sign of the NEP anomaly over Western Europe in 2003. They however disagree on the ecosystem process causing the anomalous flux. An increase in respiration causes the NEP anomaly in Biome-BGC and JULES. The increase in respiration in the above mentioned models exceeded the variance range of $1 \sigma$. In contrast, the decline in GPP exceeding $1 \sigma$ range drove the NEP anomaly in LPJ, ORCHIDEE, MOD17+ and ANN. Our analyses suggest that the differences in the models' responses to hot and dry weather in 2003 result mainly from the various descriptions of the ecosystem processes, especially soil water calculations as well as from the different representations of crops and crop management. 


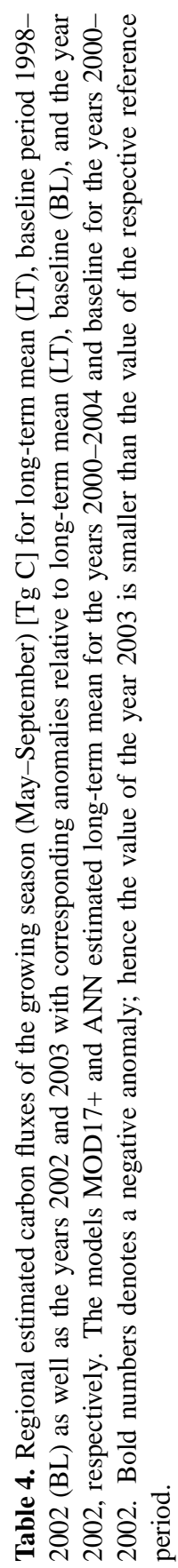

\begin{tabular}{|c|c|c|c|c|}
\hline 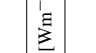 & 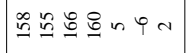 & 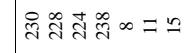 & $\frac{\infty}{\pi} \frac{a}{\pi}$ ส & $\underline{\infty} \mathscr{\infty} \Xi \mathscr{D}-0 \uparrow$ \\
\hline$\stackrel{2}{2}$ & 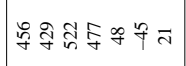 & 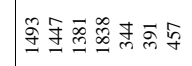 & 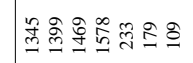 & 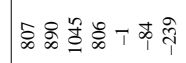 \\
\hline 焉 & 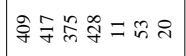 & 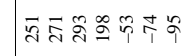 & 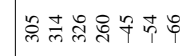 & 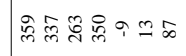 \\
\hline 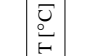 & 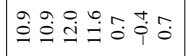 & 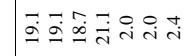 & 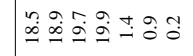 & 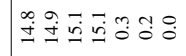 \\
\hline 2 & 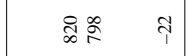 & 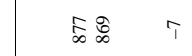 & 守葛 & 质兽 T \\
\hline$\ll$ & 宫哥茄 & œू。 & 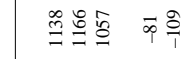 & 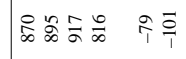 \\
\hline$\Sigma$ & 850 & 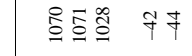 & 总莳志的昂 & 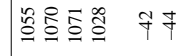 \\
\hline- & iㅛ & 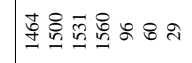 & 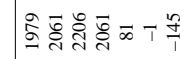 & 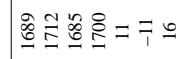 \\
\hline$\circ$ & 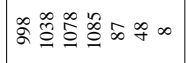 & 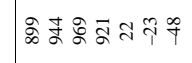 & 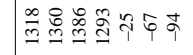 & के \\
\hline 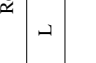 & 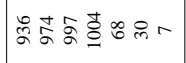 & 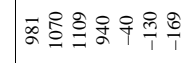 & 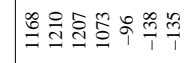 & 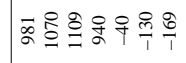 \\
\hline$\infty$ & 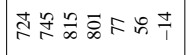 & 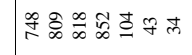 & 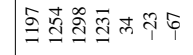 & 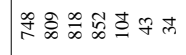 \\
\hline A & $\stackrel{\circ}{\circ}$ & 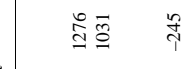 & 总点 & 号产 品 \\
\hline$<\frac{\overline{\bar{n}}}{\frac{\pi}{4}}$ & जू & (j) & 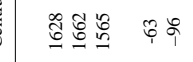 & 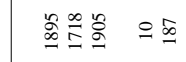 \\
\hline$\Sigma$ & 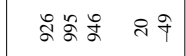 & 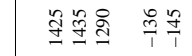 & 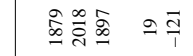 & 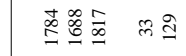 \\
\hline- & 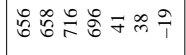 & 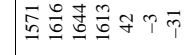 & 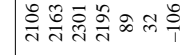 & 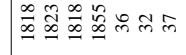 \\
\hline$\circ$ & 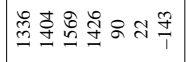 & 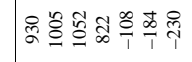 & 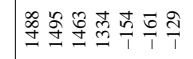 & 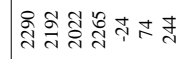 \\
\hline$\lrcorner$ & 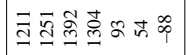 & 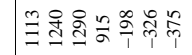 & 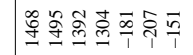 & 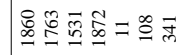 \\
\hline$\infty$ & 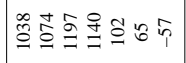 & 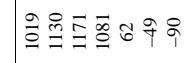 & 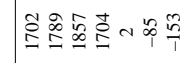 & 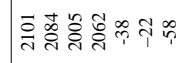 \\
\hline$a$ & $\stackrel{n}{n} \infty$ & 今。ㅇㅁ & $\stackrel{6}{n} \underset{\infty}{\frac{f}{1}}$ & 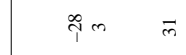 \\
\hline$\varangle$ & 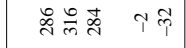 & 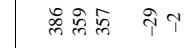 & 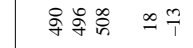 & 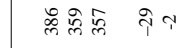 \\
\hline$\Sigma$ & 戹卢 & 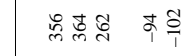 & 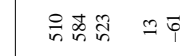 & 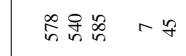 \\
\hline - & 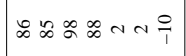 & 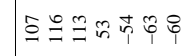 & 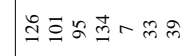 & 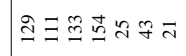 \\
\hline$\circ$ & 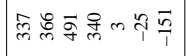 & ल & 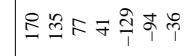 & 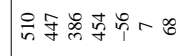 \\
\hline ــ & 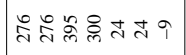 & 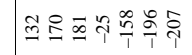 & 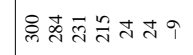 & 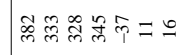 \\
\hline$\infty$ & 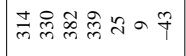 & 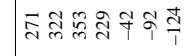 & 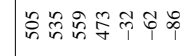 & 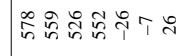 \\
\hline & تـ & 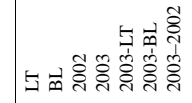 & 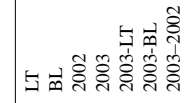 & 与 m. \\
\hline
\end{tabular}


a)

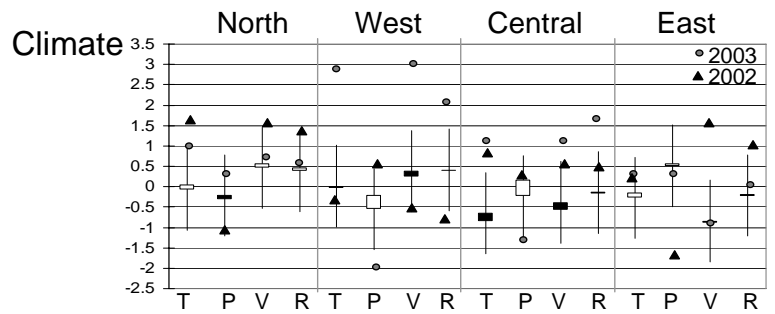

b)

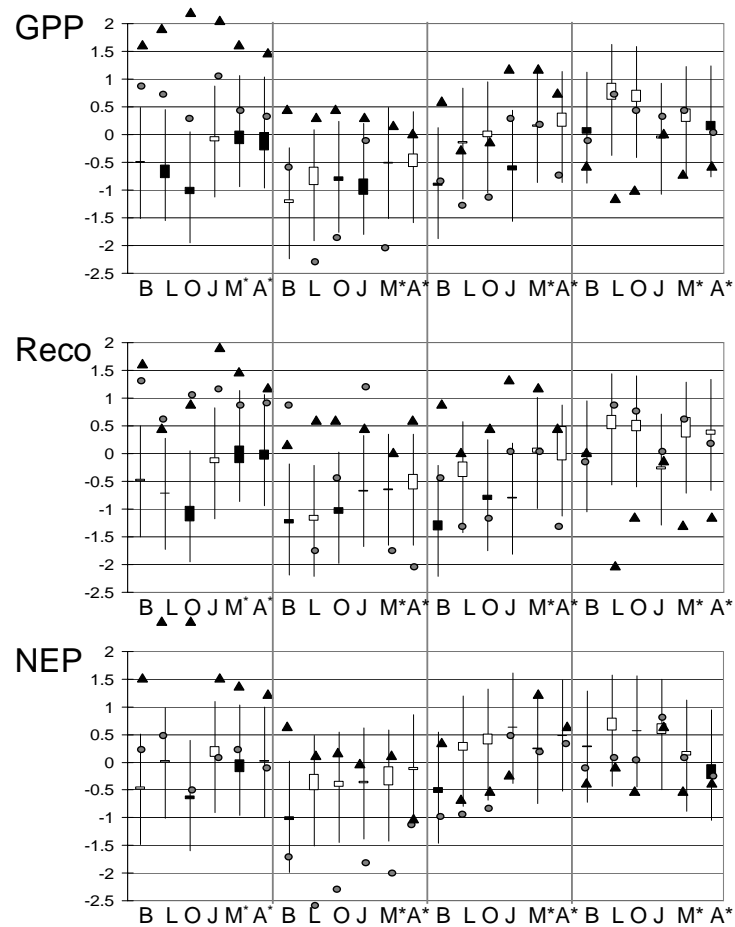

Fig. 2. Standardized area weighted (a) climate anomalies relative to baseline. T-temperature, P-Precipitation, V-Vapor pressure deficit, R-Radiation. (b) carbon flux anomalies relative to baseline. Climate and carbon anomalies are aggregated over four regions of $\mathrm{Eu}-$ rope and values are dimension less. B-Biome-BGC; L-LPJ; O- ORCHIDEE; J-JULES; M-MOD17+; A-ANN, Grey dots: anomaly in 2003 relative to baseline 1998-2002. Black triangles: anomaly in 2002 relative to baseline 1998-2002. White boxes: average value greater than median. Black boxes: average values less than median. * baseline: 2000-2002.

\subsubsection{Northern Europe}

The 2003 growing season in this region was rather warm and wet relative to the baseline and long-term (1980-2005) means. The growing season 2002 was even warmer (Fig. 2a, Table 4). All models agreed that GPP increased in both 2003 and 2002. The increase in 2002 was larger relative to both the baseline as well as the long-term mean (Fig. 2b, upper panel, Table 4). The GPP anomaly 2003 was outside the $1 \sigma$ bound for Biome-BGC, LPJ, ORCHIDEE and JULES whereas the data-oriented models showed an increase too, but not as significant. This is mainly due to the increased
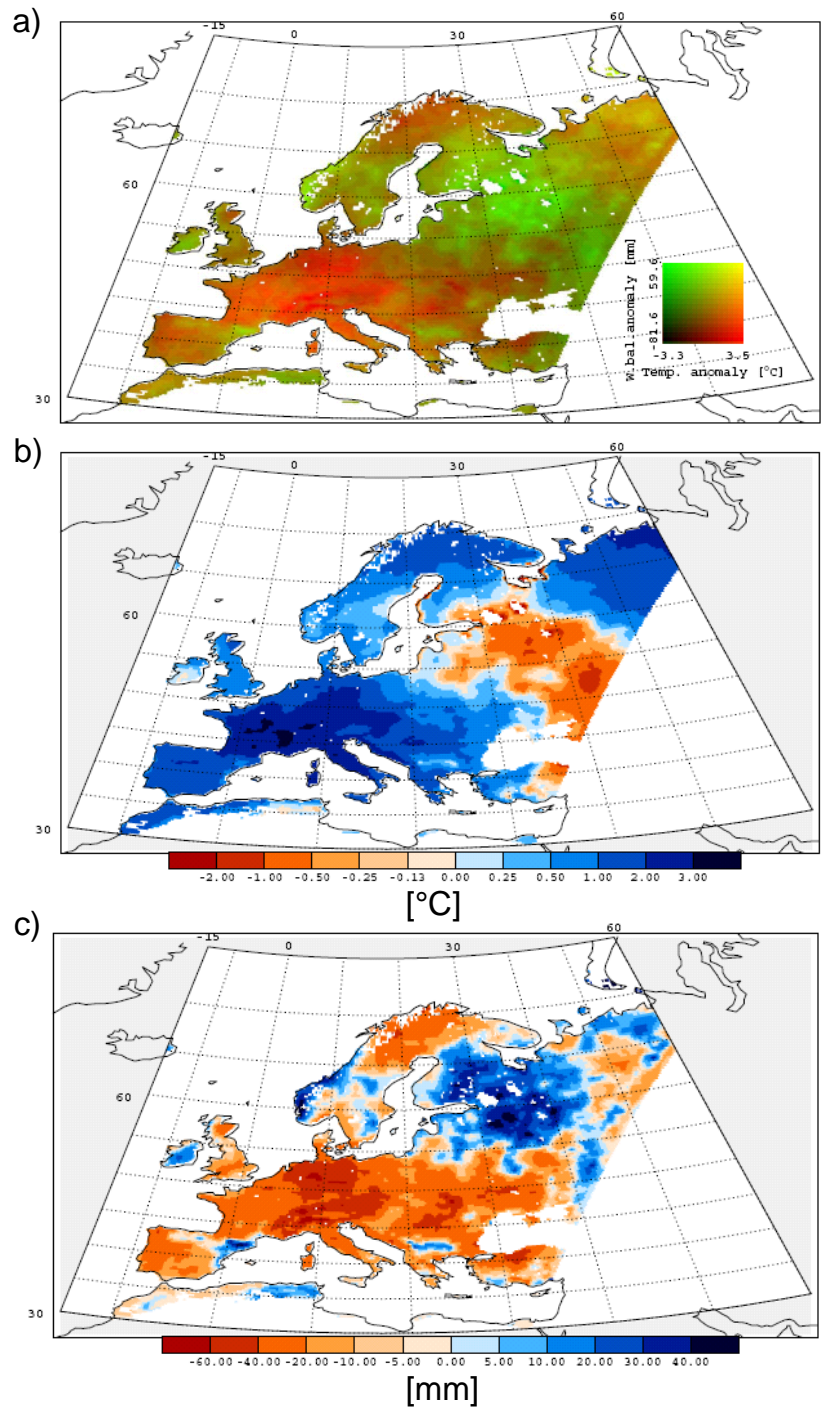

Fig. 3. The spatial pattern of the temperature and water balance anomalies through the growing season 2003 over Europe relative to baseline (1998-2002). (a) Combined spatial pattern: red areas show heat and drought, green areas show cold and wet anomaly. (b) Temperature anomaly 2003: blue areas show a temperature increase relative to baseline, red areas a decrease. (c) Water-balance anomaly 2003: blue areas: increase in water-balance relative to baseline, red areas: decrease.

temperature in this area $\left(\sim 0.7^{\circ} \mathrm{C}\right)$ relative to the baseline period of time (Table 4). This is in agreement with Churkina and Running (1998) who showed that the vegetation in the northern latitudes is temperature limited. Northern Europe is dominated by natural vegetation, mainly forests (coniferous and deciduous), which may also explain why the models showed good agreement in this region.

The Reco anomaly in 2003 followed mainly the anomaly in GPP (Fig. 2b, middle panel, Table 4). All models showed an increase in respiration in 2003 relative to both baseline and long-term mean. The increase in Reco in 2002 was 
even more pronounced, except for LPJ and ORCHIDEE. This is mainly explained by the increased temperature in both 2003 and 2002 (Fig. 2b, Table 4). Biome-BGC, LPJ, ORCHIDEE and JULES showed that the Reco anomaly 2003 was outside of the $1 \sigma$ bound whereas it was still inside the $1 \sigma$ bound for MOD17+ and ANN. Biome-BGC and PIXGRO estimated the smallest total Reco in the growing season 2003 and JULES the largest Reco among the process oriented models. The estimated Reco over the growing season 2003 as estimated by the diagnostic models (MOD17+, ANN) was smaller, but they agree with the majority of models with respect to the sign of the Reco anomaly. The reason for this behavior may be due to the fact that GPP and Reco are calculated independently in the data-oriented models, so that the link between GPP and Reco is not so strong.

The resulting standardized NEP anomaly 2003 in Northern Europe was within the range of $1 \sigma$ variance for any of the models, being close to baseline, whereas the NEP anomaly 2002 clearly indicates enhanced land carbon uptake. All models except ORCHIDEE agreed in an increased NEP in 2003 relative to baseline. In this region, the increase in temperature and radiation seem to force the increase in NEP due to enhanced photosynthesis (Churkina and Running, 1998) (Fig. 2b and Table 4). All models agreed that the NEP anomaly in 2003 relative to 2002 showed a decrease (Table 4). The range of the NEP over the growing season 2003 did not differ much among the models.

\subsubsection{Western Europe}

In 2003 this region experienced two extreme heat waves in late June and late July, and a pronounced long duration drought since the spring. The temperature increased by more than two degrees Celsius during the growing season 2003. This event was accompanied by an increase in radiation and VPD and decrease in precipitation (Fig. 2a, Table 4). During the heat waves, the temperature anomalies reached higher values, up to $10^{\circ} \mathrm{C}$ during a week (Fink et al., 2004). In 2003 all models showed a reduction in GPP. On the other hand all models agreed that GPP increased in 2002 (Fig. 2b, Table 4). The year 2002 was warm, but wetter in this region which is normally water limited. Increased precipitation leads to increased productivity. LPJ, ORCHIDEE, MOD17+ and ANN estimated the largest GPP anomaly 2003 being outside the lower $1 \sigma$ bound. Biome-BGC and JULES also showed a reduction of in GPP 2003 relative to baseline (Table 4), but the reduction was not significant (inside the $1 \sigma$ bound, Fig. $2 \mathrm{~b}$ ). The estimated reduction in GPP in 2003 is in agreement with other studies (Reichstein et al., 2006; Schindler et al., 2006; Ciais et al., 2005). Relative to the growing season 2002, the GPP anomaly over the growing season 2003 was even stronger (Table 4).

Biome-BGC and JULES estimated an increase in Reco in 2003 relative to baseline. Reco anomaly simulated by these two models was outside of the $1 \sigma$ bound (Fig. 2b, Table 4), whereas the LPJ and ORCHIDEE estimated a decrease in Reco relative to baseline still being inside the $1 \sigma$ bound. PIXGRO estimated almost no difference in Reco between 2003 and 2002 (Table 4). The sensitivity of the Reco with to respect to 2003 climate conditions seems less pronounced in Biome-BGC and JULES compared with the other process models. Both MOD17+ and ANN estimated a reduction of Reco through the growing season 2003 relative to both baseline and 2002 (Table 4). The mayor difference to the process-oriented models are the direct description of Reco based on the abiotic input in MOD17+, whereas Reco as estimated by ANN, is just the difference between the estimated NEP (-NEE) and the estimated GPP, without any explicit assumptions about the soil conditions. The 2002 Reco anomaly showed an increase in Reco in all models.

The resulting NEP anomaly in 2003 showed a decrease mostly outside the $1 \sigma$ range, with the exception of BiomeBGC, which showed a less significant decrease in comparison with the other models. All models agreed on negative NEP 2003 anomaly relative to long-term mean, baseline and 2002 as shown in Table 4. Given the very different models, all the models have been "optimized" against the measured carbon fluxes at site-level. The common response among the models reveals a high confidence in the net carbon flux responses to a particularly extreme climate anomaly in this region. This NEP anomaly is caused by the strong increase in temperature, VPD and radiation, and reduction in precipitation (Fig. 2b, Table 4), far outside the $1 \sigma$ range for all parameters. The growing season 2003 experienced a severe heat period and corresponding soil moisture deficit whereas the growing season 2002 did not show large deviations from baseline with a corresponding NEP anomaly 2002 being closer to baseline estimated by all models. The total NEP over the growing season 2003 differed strongly between the models. Biome-BGC, MOD17+, ANN and PIXGRO estimated the total NEP over the growing season 2003 to $229 \mathrm{Tg}, 262 \mathrm{Tg}, 357 \mathrm{Tg}$ and $162 \mathrm{Tg}$ respectively (Table 4). LPJ, ORCHIDEE and JULES estimated NEP values of the growing season 2003 close to neutral, the two first even estimated a negative NEP in $2003,-25 \mathrm{Tg}$ and $-99 \mathrm{Tg}$ respectively (Table 4). The large differences among the models are mainly due to the different treatment of the crop-lands (see discussion below).

\subsubsection{Central Europe}

In Central Europe the GPP anomaly in 2003 was less pronounced than in Western Europe (Fig. 2a middle panel, Table 4). This is also in agreement with the less pronounced climate anomaly in this region (Fig. 2b). Biome-BGC, LPJ, ORCHIDEE and ANN agreed in a reduction in GPP relative to baseline, the three latter also relative to the long-term mean (Table 4). The decrease was even larger relative to the growing season 2002. JULES and MOD17+ showed an increase of the GPP anomaly in 2003, but agreed in a reduction of the 

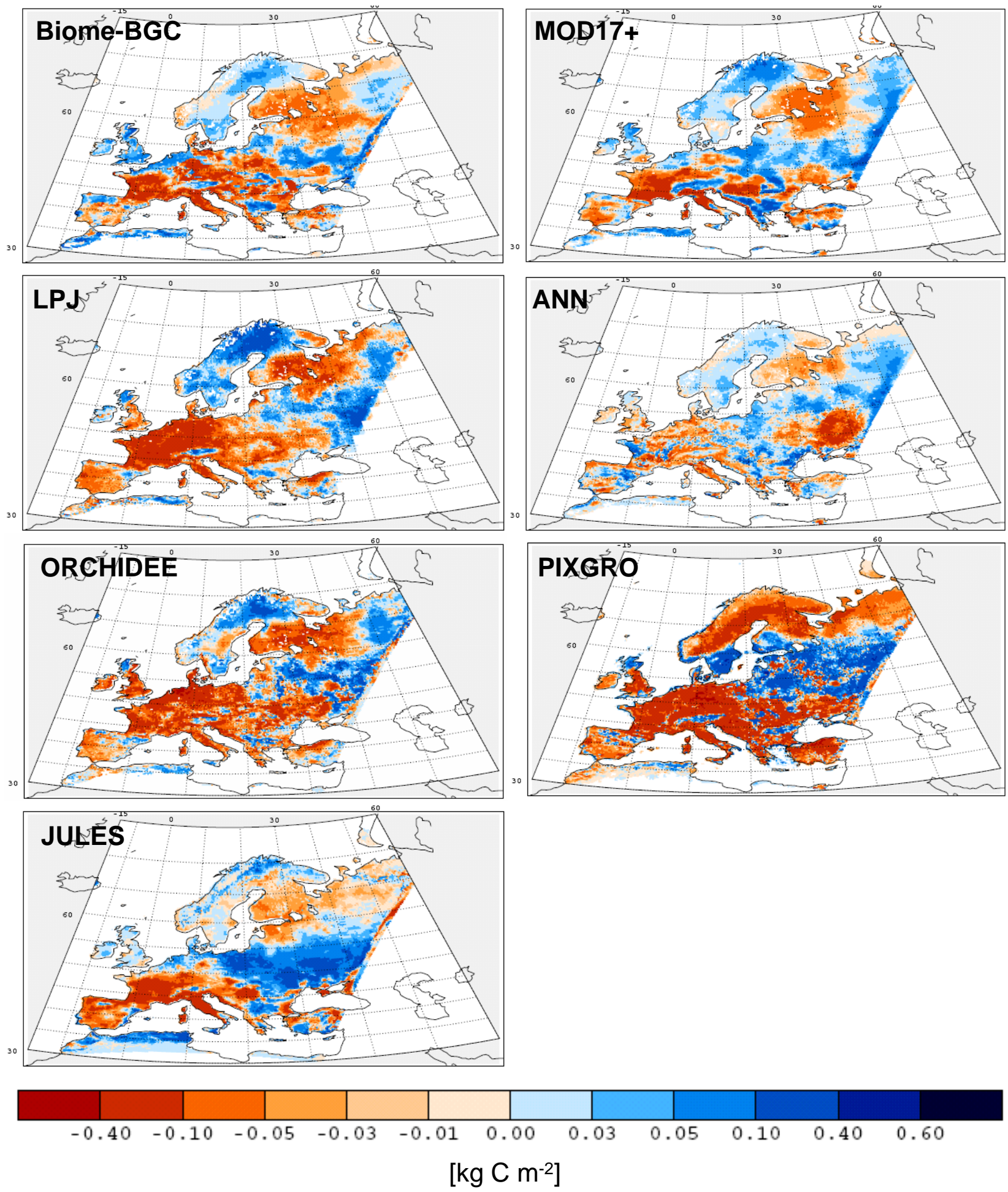

Fig. 4. Anomaly in net ecosystem production in 2003 relative to baseline (1998-2002). Red areas show reduction in NEP. Blue areas show increase in NEP. For MOD17+ss and ANN the anomaly is calculated relative to the average between 2000 and 2002 (MODIS started December 1999). PIXGRO shows the difference in NEP between 2003 and 2002. 
Table 5. Total European carbon fluxes $[\mathrm{Pg}]$ and their anomalies calculated for the growing season (May-September) and the corresponding annual anomalies (in brackets). The calculated fluxes are averages over 1980-2005 (long-term mean), over 1998-2002 (baseline), and total sums for the years 2002 and 2003. Corresponding estimated anomalies are calculated relative to longterm mean, baseline and 2002 for Biome-BGC, LPJ, ORCHIDEE, JULES, MOD17+, ANN and PIXGRO. Bold numbers denote that the carbon fluxes over the growing season 2003 were smaller than over the respective reference period.

\begin{tabular}{|c|c|c|c|c|c|c|c|}
\hline & \multicolumn{7}{|c|}{ Model } \\
\hline & Biome-BGC & LPJ & ORCHIDEE & JULES & MOD17+ & ANN & PIXGRO \\
\hline \multicolumn{8}{|l|}{ GPP } \\
\hline Long-term mean & $5.86(6.44)$ & $5.65(7.00)$ & $6.04(8.28)$ & $6.15(7.92)$ & & & \\
\hline baseline & $6.08(6.71)$ & $5.75(7.22)$ & $6.10(8.56)$ & $6.26(8.15)$ & $6.01(7.60)$ & $5.76(7.24)$ & \\
\hline 2002 & $6.23(6.86)$ & $5.65(7.23)$ & $6.10(8.84)$ & $6.48(8.45)$ & $6.14(7.69)$ & $5.66(7.14)$ & $5.00(6.71)$ \\
\hline 2003 & $5.99(6.57)$ & $5.38(6.73)$ & $5.85(8.01)$ & $6.36(8.03)$ & $5.95(7.30)$ & $5.61(6.78)$ & $4.58(6.09)$ \\
\hline 2003-long-term mean & $0.13(0.12)$ & $-0.27(-0.27)$ & $-0.20(-0.27)$ & $0.21(0.11)$ & & & \\
\hline 2003-baseline & $-0.09(-0.14)$ & $-0.37(-0.49)$ & $-0.25(-0.55)$ & $0.10(-0.12)$ & $-0.06(-0.30)$ & $-0.14(-0.46)$ & \\
\hline 2003-2002 & $-0.24(-0.29)$ & $-0.27(-0.50)$ & $-0.26(-0.83)$ & $-0.12(-0.42)$ & $-0.19(-0.39)$ & $-0.05(-0.35)$ & $-0.42(-0.62)$ \\
\hline \multicolumn{8}{|l|}{ Reco } \\
\hline Long-term mean & $4.19(6.20)$ & $4.56(7.07)$ & $5.00(8.28)$ & $5.70(7.80)$ & & & \\
\hline baseline & $4.33(6.43)$ & $4.68(7.28)$ & $5.09(8.33)$ & $5.85(8.08)$ & $4.24(7.58)$ & $3.94(5.65)$ & \\
\hline 2002 & $4.41(6.49)$ & $4.52(7.48)$ & $5.07(8.36)$ & $6.04(8.32)$ & $4.27(7.55)$ & $3.89(5.58)$ & $4.12(6.25)$ \\
\hline 2003 & $4.39(6.45)$ & $4.54(6.63)$ & $5.11(8.16)$ & $5.93(7.94)$ & $4.24(7.41)$ & $3.83(5.29)$ & $4.11(6.09)$ \\
\hline 2003-long-term mean & $0.20(0.25)$ & $-0.02(-0.44)$ & $0.12(0.09)$ & $0.23(0.14)$ & & & \\
\hline 2003-baseline & $0.06(0.02)$ & $-0.14(-0.65)$ & $0.02(-0.17)$ & $0.08(-0.14)$ & $-0.003(-0.17)$ & $-0.12(-0.36)$ & \\
\hline 2003-2002 & $-0.02(-0.04)$ & $0.03(-0.85)$ & $0.04(-0.20)$ & $-0.11(-0.38)$ & $-0.03(-0.14)$ & $-0.06(-0.29)$ & $-0.01(-0.15)$ \\
\hline \multicolumn{8}{|l|}{ NEP } \\
\hline Long-term mean & $1.67(0.23)$ & $1.09(-0.07)$ & $1.05(0.22)$ & $0.45(0.11)$ & & & \\
\hline baseline & $1.74(0.27)$ & $1.06(-0.06)$ & $1.01(0.24)$ & $0.41(0.07)$ & $1.77(0.02)$ & $1.81(1.59)$ & \\
\hline 2002 & $1.82(0.37)$ & $1.13(-0.25)$ & $1.04(0.48)$ & $0.44(0.12)$ & $1.87(0.14)$ & $1.78(1.56)$ & $0.88(0.46)$ \\
\hline 2003 & $1.59(0.11)$ & $0.83(0.10)$ & $0.74(-0.15)$ & $0.43(0.08)$ & $1.71(-0.11)$ & $1.79(1.49)$ & $0.47(0.00)$ \\
\hline 2003-long-term mean & $-0.08(-0.12)$ & $-0.26(0.17)$ & $-0.31(-0.37)$ & $-0.02(-0.03)$ & & & \\
\hline 2003-baseline & $-0.15(-0.16)$ & $-0.23(0.16)$ & $-0.27(-0.38)$ & $0.02(0.02)$ & $-0.06(-0.13)$ & $-0.03(-0.10)$ & \\
\hline 2003-2002 & $-0.23(-0.26)$ & $-0.30(0.35)$ & $-0.30(-0.63)$ & $-0.01(-0.04)$ & $-0.16(-0.25)$ & $0.01(-0.07)$ & $-0.41(-0.46)$ \\
\hline
\end{tabular}

GPP in 2003 versus 2002. Also PIXGRO estimated a strong reduction in GPP over the growing season 2003 relative to 2002.

Biome-BGC and JULES estimated an increase in Reco in 2003 relative to long-term mean (Table 4), but being close to baseline (Fig. 2b, middle panel, Table 4). ANN showed a decrease in the Reco anomaly 2003 which was outside the $1 \sigma$ range (Fig. 2a, lower panel). All other models estimated the 2003 carbon flux anomaly to be inside the $1 \sigma$ bound. All models agreed in an increase in the Reco anomaly in 2002.

The NEP anomaly in 2003 showed mainly the same pattern as for Western Europe for the models Biome-BGC, LPJ and ORCHIDEE, but the decrease in NEP was not as significant (Fig. 2b, lower panel). Also the climate anomaly over Central Europe showed the same tendency, all parameters showing mainly the same pattern as for Western Europe, only less significant (Fig. 2a, Table 4). JULES, MOD17+ and ANN showed a slightly increased NEP but not outside of the $1 \sigma$ range (Fig. 2a, upper panel). The NEP anomaly in 2002 was slightly less prominent compared with 2003 for the models LPJ, ORCHIDEE and ANN, whereas the estimated NEP anomaly 2002 showed a stronger increase for Biome-BGC, MOD17+ and ANN. JULES showed that the NEP anomaly 2002 was more decreased compared with 2003.

\subsubsection{Eastern Europe}

All models agreed that the GPP carbon flux anomaly in 2003 relative to baseline was small (Fig. 2b, upper panel). BiomeBGC was the only model which estimated a small decrease in GPP in 2003 (Table 4). LPJ, ORCHIDEE, JULES, MOD17+ and ANN showed an increase in GPP anomaly relative to baseline (Fig. 2b, upper panel, Table 4).

The Reco anomaly in 2003 was close to the long-term mean of the anomalies 1980-2005 (Fig. 2b, middle panel). Except Biome-BGC and JULES all models estimated an increase in respiration in 2003. The Reco anomaly in 2002 decreased strongly in all models (being outside of the $1 \sigma$ range), except for Biome-BGC and JULES which estimated the 2002 anomaly to be close to baseline.

The NEP anomaly in 2003 was inside the $1 \sigma$ range for all models and did not differ much from the carbon flux anomaly in 2002 (Fig. 2b, Table 4). All models agreed in a positive NEP over the growing season 2003. PIXGRO estimated a NEP over the growing season 2003 close to 0. All models agreed in the sign of the NEP anomaly in Western Europe, which was also the region which experienced the strongest heat anomaly and soil water deficit as estimated by REMO. 
a)

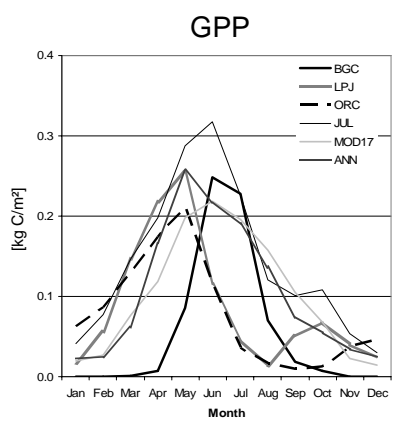

b)

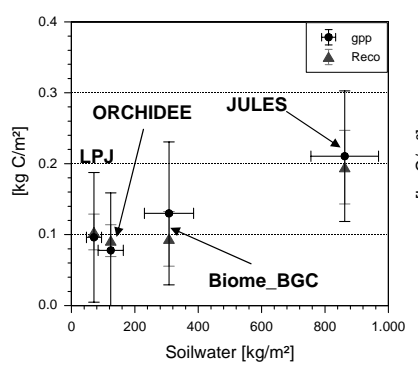

c)
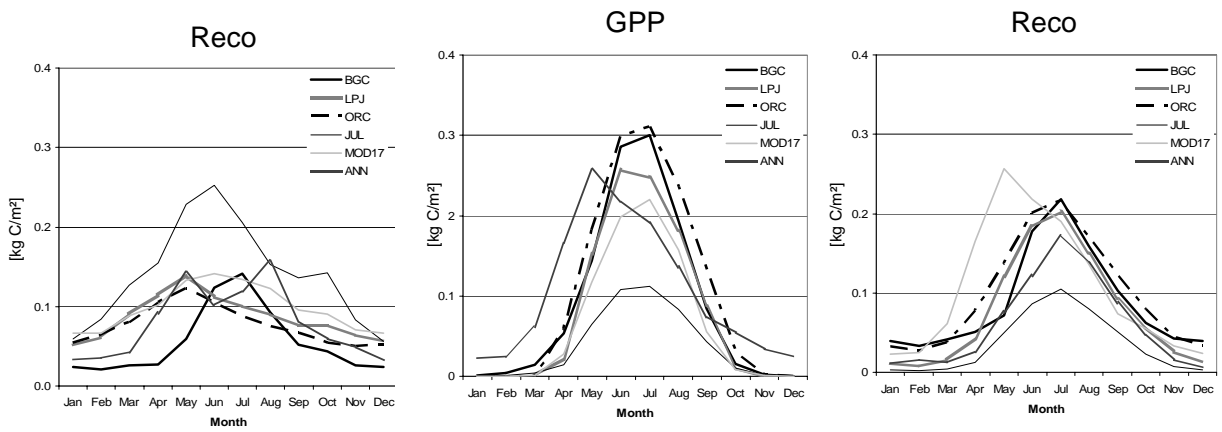

d)

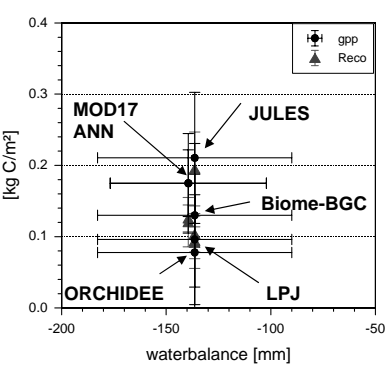

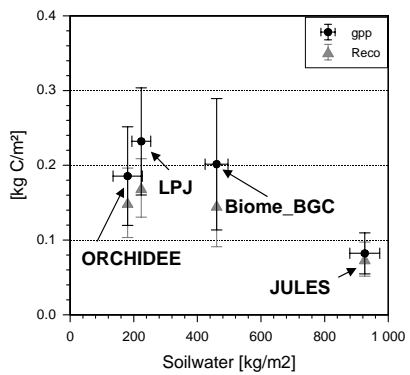

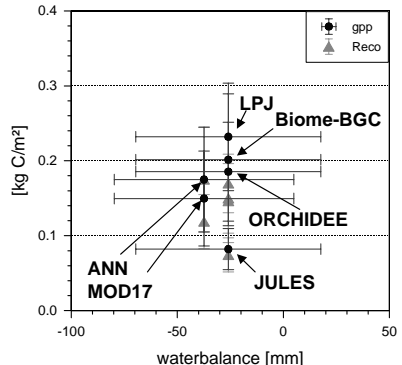

Fig. 5. Seasonal average variation of GPP and Reco over the baseline period 1998-2002 for (a) crops, and (c) evergreen needleaf forests, the corresponding relationship with modeled soil water content and the water balance (estimated from precipitation, shortwave radiation and temperature) for (b) crops and (d) evergreen needleaf forests. Error bars denote averaged monthly standard deviation over the baseline period from 1998 to 2002. Due to technical reasons JULES was run with soil depth equal $3 \mathrm{~m}$ for all land-cover types.

\section{Why do the models differ in their gross carbon flux responses to the 2003 climate anomaly?}

The reasons for the different GPP and Reco responses to the climate anomalies among different models can be summarized as follows:

(i) The first reason is various treatment of the crop/cropland phenology among the models. Biome-BGC, ORCHIDEE and JULES represent the crops with fertilized grasses, super grasses and natural grasses respectively, with no harvest. Thus, GPP is accumulated over the whole period and the grass/crop is left to senescence. This causes a larger standing biomass, which results in larger autotrophic respiration (mainly maintenance respiration) and a higher heterotrophic respiration due to larger litter and soil organic matter pools compared with models including harvest. In contrast to Biome-BGC, ORCHIDEE and JULES, LPJ and PIXGRO account for the management of the crops. In LPJ, harvest is determined through a sum over growing degree days (Bondeau et al., 2007) which determines maturity, thereafter the crop is harvested. In 2003 the warm temperatures accelerated the maturity-processes, and crops were harvested earlier compared with not so warm periods. Hence the time for assimilating carbon was also shorter. In addition less biomass is left to senescence and cause less heterotrophic respiration compared with the other models. PIXGRO use a simple climate zone dependence to establish the sawing and harvesting of the crops. The data-oriented models, both MOD17+ and ANN have a direct connection between the abiotic factors and GPP and have no direct coupling with the soil-processes, further the harvesting is implicit through the input data (satellite fAPAR, and measured NEE, respectively).

(ii) The second reason is related to representation of carbon flux responses to drought in different process-oriented models. This response is a function of the more or less detailed soil structure, biogeochemistry and soil hydrology. Only Biome-BGC utilizes a single bucket soil module, which allows all water not being run-off or evaporated to be available for the plants. The other process models utilize at least a two layer soil model, which allows the upper layer to dry faster than the lower layers. These models have also a differentiated vertical root distribution, where grasses have most of the roots in the upper layer (short rooting depth) and shrubs and trees have deeper rooting depths. In this way the estimated drought effect of grasses is stronger in these models than compared with Biome-BGC. In LPJ, $80 \%$ of the below ground biomass for the grass and crop types, is situated in the upper layer which also experience the largest evaporation and drought stress. 
Both ORCHIDEE and JULES have a hourly resolution (Table 2), and, hence are capable of simulating the effects of peak daytime evaporative demand on ecosystem water stress. This is especially important because the anomaly of maximum daytime temperature during the heat waves was higher than the anomaly of the nighttime temperatures. This resolution of the diurnal cycle enables ORCHIDEE and JULES to simulate rapid increases in transpiration and decomposition after a short rain event, which leads to a stronger subdaily variation of Reco than compared to Biome-BGC (daily variation) and LPJ (monthly variation). Also differences in the model simulations of evapotranspiration occur due to the differences in soil structure. JULES utilizes a four layer soil module where the decomposition of soil organic carbon is only sensitive to soil humidity and temperature in the upper $10 \mathrm{~cm}$. Depending on the root distribution, the decomposition and water availability is more or less drought sensitive. PIXGRO has also a high temporal resolution, but the productivity is decoupled from the soil processes (Table 1). PIXGRO estimated almost no change on Reco between 2003 and 2002.

Furthermore, vegetation feedbacks on soil moisture play an important role in understanding the variations in GPP and Reco. Biome-BGC estimates canopy conductance as a direct function of atmospheric VPD, soil-water potential and minimum temperature. In 2003 VPD was regionally extremely high, and therefore simulated stomatal conductance and transpiration in Biome-BGC were strongly reduced. Higher plant available water causes in Biome-BGC the microbial activity to increase, enhancing the decomposition of soil organic matter. This may lead to increased soil mineral N, which in turn increases GPP also under water stressed conditions hence reducing the drought reduction in GPP compared with the other models (LPJ, ORCHIDEE, JULES and PIXGRO). JULES estimates an even less reduction in GPP, which shows that this model seems to be less sensitive to drought stress, a direct impact of the differentiated soil water distribution and the below-ground biomass distribution (Table 1).

(iii) The sensitivity of carbon fluxes to drought varies from model to model and can be directly related to the different modeling approaches. Models which simulate crop or grass harvest seem to have higher drought sensitivity than models without harvest which may be due to increased bare-soil evaporation. Also the sensitivity to drought is higher in the models utilizing a two layer soil hydrology model. JULES has a very detailed soil hydrology and seems to be the least drought sensitive model used in this study. It has yet to be determined whether the different model sensitivities to drought are due to the carbon components sensitivity to soil moisture, or different hydrology schemes simulating different soil drying under the same climate forcings. Guo and Dirmeyer (2006) showed that many hydrology models simulate interannual variability of soil moisture better than the absolute values. However, the carbon flux sensitivity to drying will depend on the baseline level as well as the anomaly.
Hence, our findings illustrate the need of further model development and model evaluation against site-level measurements and inventories, including soil moisture observations where available, which may reduce the model differences and increase the reliability of the model estimated European carbon balance in the future.

5.1 Spatial patterns of the climate and carbon flux anomalies in 2003

In 2003 the climate anomaly over Europe showed across all the models a typical dipole pattern (Fig. 3). Western and Central Europe were exposed to a strong heat and drought anomaly, which was more prominent in western parts than in the central region. Eastern Europe exhibited a cold and wet anomaly. The region between these major anomalies exhibited intermediate conditions. This climate anomaly pattern was also seen in the spatial NEP anomaly in 2003 (Fig. 4).

In 2003, the NEP decreased over large areas of Europe (Fig. 4, areas in red color), showing a clear dipole pattern. These affected areas correspond directly to the climate anomalies over the same time period (Fig. 3). LPJ, ORCHIDEE and PIXGRO estimated greater affected areas (5.18 $10^{6}, 5.4210^{6}$ and $5.6410^{6} \mathrm{~km}^{2}$ respectively) than JULES, Biome-BGC, MOD17+ and ANN (4.19 106 , $4.7610^{6}, 3.93$ $10^{6}$ and $3.3710^{6} \mathrm{~km}^{2}$ respectively). The three latter models estimated a more heterogeneous pattern over Western and Central Europe. Models agreed well in the spatial pattern of vegetation responses to the cold and wet anomaly. There is an area with increased carbon sequestration (blue colors) between the dry and warm area, and the cold and wet area. MOD17+, ANN and JULES show the greatest extent of this area in Eastern Europe. All models agreed that the 2003 NEP anomaly was positive over Scandinavia and North Eastern Russia. The spatial pattern of 2003 anomaly estimated by PIXGRO differs relative to the other models especially for Northern and North Eastern Europe as the growing season 2002 is used for the anomaly estimate. As shown earlier, the growing season 2002 was exceptionally warm in comparison with both 2003 and baseline for this area (Fig. 2a, Table 4). This caused an increased productivity in 2002 relative to 2003. Nevertheless, the good agreement in the spatial pattern of the net ecosystem productivity anomaly in 2003 among models of different complexity and structure sugest a good confidence in this pattern. However, the differences in gross fluxes across the models, suggests that much work remains to be done to quantify the response of ecosystem C fluxes to climate. Reichstein et al. (2006) showed that on a transect through Europe most site-measurements of NEP showed a negative averaged monthly NEP anomaly (JulySeptember) as the difference between 2003 and 2002. In Germany, southern upper Rhine plain, the measured NEE in August and September 2003 was significantly lower than in 2004 (Schindler et al., 2006). Jolly et al. (2005) also showed 
that the heat wave in 2003 caused an increased productivity in the Alps, which could also be seen in all models.

\subsection{Contribution of the European carbon flux anomaly to the atmosphere in 2003}

The length of the period chosen as reference influences the prominence of the anomalous event. In most models the prominence of 2003 anomaly declined with lengthening of the reference period from one year to 16 years (Table 4, Table 5). The 2003 anomaly for annual net carbon fluxes ranged between 0.35 and $-0.63 \mathrm{Pg} \mathrm{C}$ for a reference period of one year and between 0.17 and $-0.37 \mathrm{Pg} \mathrm{C}$ for a reference period of 16 years for the whole Europe.

Independent of the reference period (long-term mean, baseline or 2002) all models agreed on an anomalous carbon release from the European ecosystems to the atmosphere in 2003 (Table 5). Over the growing season 2003 the European ecosystems emitted between $0.002-0.27 \mathrm{Pg}$ of carbon to the atmosphere. Using the baseline period (1998-2002) Ciais et al. (2005) estimated the anomaly of the summer 2003 (JulySeptember) for Europe to be $-0.5 \mathrm{Pg}$ using ORCHIDEE (with a different forcing than in this study). This value is larger than the maximum value in our study $(-0.27 \mathrm{Pg}$, ORCHIDEE) which can be related to different definitions of the growing season in these two studies (May-September in this study, relative to July-September in Cias et al., 2005). The growing season 2002 was obviously not an average year, being wetter and more productive than the long-term mean and the baseline for most of the models. Using this year to estimate the carbon flux anomaly of the growing season 2003, would lead to a high estimate of the anomalous flux ranging between 0.01 and $0.41 \mathrm{Pg}$. The additional carbon flux from land to the atmosphere resulted from a reduced gross primary productivity which reduction was between $-0.37 \mathrm{Pg}$ and $0.06 \mathrm{Pg}$ relative to baseline over whole Europe. One model (JULES) estimated an increase in gross primary productivity of $0.19 \mathrm{Pg}$ over the growing season 2003. All models agreed on a reduction of GPP in the growing season 2003 relative to 2002. Biome-BGC, ORCHIDEE and JULES estimated an overall increase in ecosystem respiration in 2003 relative to baseline of $0.06,0.02$ and $0.12 \mathrm{Pg}$, respectively. The other models LPJ, MOD17+ and ANN, indicated a total decrease of ecosystem respiration over the growing season 2003 of $0.14,-0.003$ and -0.12 Pg relative to baseline, respectively.

All models except ANN showed that the effect of 2003 drought on the annual carbon budget was lower than on the carbon budget of the growing season. Most likely is this a result of a diversity of vegetation types across Europe.

In Fig. 5 we have plotted the average seasonal variation of the GPP and Reco over the baseline period of the models respectively, as well as the averaged monthly values of GPP and Reco in dependence of soil-water and water-balance. We selected two 1 by 1 degree areas which were dominated by crop and conifers respectively. In each of these areas we selected the 0.25 by 0.25 degree grid cells that contained more than 90\% land cover of crop (Western Europe Carbon anomaly: 5 grid cells) and of conifers (North Eastern European carbon anomaly: 9 grid cells), respectively. The process-models showed a clear relation in the average GPP and Reco during the baseline period with the modeled soilwater content. Especially JULES shows a very high soilwater content for both land cover types, which may be due to the different soil-depth used in the simulations. Due to the exponential distribution of the root-depth, not all of the soilwater are available for the plants (trees reaches larger depths that grasses).

The models show a very different seasonal behavior for the crop site. LPJ and ORCHIDEE show a very early increase in GPP and respiration where as MOD17, ANN and especially Biome-BGC show an increase later in spring. The overall maximum of the GPP does not differ greatly amongst the models. Conversely, JULES calculated the highest Reco which may be due to a combination of the larger soil-depth and the larger soil-carbon pools. LPJ is showing two different respiration peaks during the year associated with regrowth of grasses after harvest, whereas the other models have the highest respiration in May or June. The conifer grid cells show a much more comparable variation of GPP and Reco between the models over the year baseline period. Only the averaged maximum differs slightly which is mostly a result of the temperature sensitivity (see Jung et al., 2007). These results highlight our overall conclusion that the major differences among the models are due to their treatments of crop functioning, which is aggravated by the lack of crop specific parameterization in most of the models (except LPJ) and the crop specific management. The European carbon flux in the growing season of 2003 is dominated by the ecosystems experiencing extreme drought. The annual carbon budget is, however, composed of contributions from more diverse ecosystems types and is overall less responsive to climate anomalies.

\section{Conclusions}

Our multi-model comparison study suggests that land ecosystems of Europe emitted additional $0.02-0.27 \mathrm{Pg}$ of carbon to the atmosphere in response to the drought in 2003 relative to baseline carbon release (1998-2002). Our estimates are lower than the previously reported value $(0.5 \mathrm{Pg}$, Ciais et al., 2005), which was calculated with the ORCHIDEE ecosystem model over a two-month shorter period of time (July-September) and thus yielded a stronger anomaly. Our study shows that a heat and drought anomaly over Western and Central Europe was accompanied by a cold and wet anomaly over Western Russia. All models agreed on the negative ecosystem responses to both the hot and dry as well as the cold and wet climate anomalies. 
The models differ in their GPP and Reco responses to the hot and dry anomaly in Western and Central Europe. The diagnostic models estimated less variation in Reco compared to the process-oriented models. The links between GPP, Reco, and belowground processes should be revisited in the model structure for both, the process-oriented and the diagnostic models. A detailed data-model comparison exercise aiming to identify model abilities and uncertainties with emphasis on the response to drought is currently underway (Jung, personal communication).
An interesting question to explore is how the 2003 drought influences the functioning of land ecosystems in the following years. Previous studies suggested that effect of anomalous climatic events could be detected in the ecosystem carbon fluxes for at least 3-5 years after the event's occurrence and ecosystem responses could be discontinuous (Schimel et al., 2005). Given that European ecosystems experienced drought again in 2005 the recovery of ecosystems will most likely take longer and should be investigated in the future. 
Table A1. Detailed description of the process photosynthesis for the process-models Biome-BGC (BGC), Lund-Potsdam-Jena managed Land (LPJ), ORCHIDEE (ORC), JULES (JUL) and PIXGRO (PIX).

\begin{tabular}{|c|c|c|c|c|c|c|c|}
\hline Process & Model & Basic Equations & $\begin{array}{l}\text { Response to tempera- } \\
\text { ture }\end{array}$ & $\begin{array}{l}\text { Response to soil } \\
\text { water }\end{array}$ & $\begin{array}{l}\text { Response to radi- } \\
\text { ation }\end{array}$ & $\begin{array}{l}\text { Response to air hu- } \\
\text { midity }\end{array}$ & $\begin{array}{l}\text { Response to nitro- } \\
\text { gen availability }\end{array}$ \\
\hline \multirow[t]{5}{*}{ Photo-synthesis } & BGC & $\begin{array}{l}\text { Maximum rate from } \\
\text { (De Pury and Farquhar } \\
\text { 1997, Woodrow and } \\
\text { Berry 1980) for shaded } \\
\text { and unshaded canopy } \\
\text { parts }\end{array}$ & $\begin{array}{l}\text { Through } \\
\text { stomatal conductance }\end{array}$ & $\begin{array}{l}\text { Through stom- } \\
\text { atal } \\
\text { conductance }\end{array}$ & $\begin{array}{l}\text { Through stom- } \\
\text { atal conductance }\end{array}$ & $\begin{array}{l}\text { Through stomatal } \\
\text { conductance }\end{array}$ & $\begin{array}{l}\text { According to rela- } \\
\text { tionship between } \\
\text { nitrogen demand } \\
\text { and soil nitrogen } \\
\text { availability }\end{array}$ \\
\hline & LPJ & $\begin{array}{l}\text { Farquhar photosynthe- } \\
\text { sis model (Farquhar et } \\
\text { al., 1980, Farquhar and } \\
\text { von Caemmerer, 1982) } \\
\text { general. for glob. mod- } \\
\text { elling purp. (Collatz et } \\
\text { al., 1991, 1992). Opti- } \\
\text { mization of the Rubisco } \\
\text { capacacity to maxim. } \\
\text { the daily rate of net } \\
\text { photosynthesis (Haxel- } \\
\text { tine \& Prentice 1996) }\end{array}$ & $\begin{array}{l}\text { PFT-specific tempera- } \\
\text { ture inhibition func- } \\
\text { tion limiting photo- } \\
\text { synthesis at low and } \\
\text { high temperature }\end{array}$ & $\begin{array}{l}\text { Through stom- } \\
\text { atal conductance }\end{array}$ & $\begin{array}{l}\text { Colimitation by } \\
\text { light and Rubisco } \\
\text { activity }\end{array}$ & & \\
\hline & ORC & (Farquhar et al., 80) & $\begin{array}{l}\text { Bowl shape func- } \\
\text { tion,adapt. to local } \\
\text { temp. } \\
\text { Tmin }=-2^{\circ} \mathrm{C} \text {, } \\
\text { Topt }=25^{\circ} \mathrm{C} \text {, } \\
\text { Tmax }=38^{\circ} \mathrm{C}\end{array}$ & $\begin{array}{l}\text { Through stom- } \\
\text { atal } \\
\text { conductance }\end{array}$ & $\begin{array}{l}\text { Saturating } \\
\text { Rubsico regener- } \\
\text { ation } \\
\text { rate }\end{array}$ & $\begin{array}{l}\text { Through stomatal } \\
\text { conductance }\end{array}$ & \\
\hline & JUL & $\begin{array}{l}\text { Collatz et } \\
\text { al. (1991)/Collatz } \\
\text { et al. (1992). } \\
\text { See also Annex A of } \\
\text { Cox (2001), and figure } \\
7 \text { of Cox et al. (1998) }\end{array}$ & $\begin{array}{l}\text { PFT spec. function, } \\
\text { adapt. derived from } \\
\text { Collatz et al. (1991)/ } \\
\text { Collatz et al (1992) } \\
\text { to local temp., gov. by } \\
\text { PFT spec. Tlow and } \\
\text { Tup }\end{array}$ & $\begin{array}{lr}\text { Response } & \text { corr. } \\
\text { for by a } & \text { soil } \\
\text { moist. avail. } & \text { avior } \\
\text { factor weight. } \\
\text { through } 4 \text { soil } \\
\text { levels acc. } \text { to } \\
\text { PFT spec. root } \\
\text { depth }\end{array}$ & $\begin{array}{l}\text { Saturating func- } \\
\text { tion of incident } \\
\text { PAR }\end{array}$ & $\begin{array}{l}\text { Through stomatal } \\
\text { conductance }\end{array}$ & \\
\hline & PIX & (Farquhar et al., 1980) & $\begin{array}{l}\text { Enzyme } \\
\text { tive./deactiv. } \\
\text { Falge et al., } \\
\text { Owee en } \\
\text { tuned to leaf chamber } \\
\text { data }\end{array}$ & $\begin{array}{l}\text { Patchy closure } \\
\text { reduces effective } \\
\text { leaf area }\end{array}$ & $\begin{array}{l}\text { Saturating } \\
\text { Rubsico regener- } \\
\text { ation } \\
\text { rate }\end{array}$ & $\begin{array}{l}\text { Via stomatal con- } \\
\text { ductance diffusion } \\
\text { influence }\end{array}$ & \\
\hline
\end{tabular}


Table A2. Detailed description of the process stomatal conductance for the process-models Biome-BGC (BGC), Lund-Potsdam-Jena managed Land (LPJ), ORCHIDEE (ORC), JULES (JUL) and PIXGRO (PIX).

\begin{tabular}{|c|c|c|c|c|c|c|c|}
\hline Process & Model & Basic Equations & $\begin{array}{l}\text { Response to tem- } \\
\text { perature }\end{array}$ & $\begin{array}{l}\text { Response to soil } \\
\text { water }\end{array}$ & $\begin{array}{l}\text { Response to radi- } \\
\text { ation }\end{array}$ & $\begin{array}{l}\text { Response to air hu- } \\
\text { midity }\end{array}$ & $\begin{array}{l}\text { Response to nitro- } \\
\text { gen availability }\end{array}$ \\
\hline \multirow[t]{5}{*}{$\begin{array}{l}\text { Stomatal- conduct- } \\
\text { ance }\end{array}$} & BGC & $\begin{array}{l}\text { Maximum cond. is veg. } \\
\text { type specific. It is re- } \\
\text { duced by scalars dep. } \\
\text { on temp., water, radia- } \\
\text { tion and air humidity } \\
\text { (Thornton 1998) }\end{array}$ & $\begin{array}{l}\text { Nonlinear dep. } \\
\text { on daylight temp. } \\
\text { Rastetter et al. } \\
(1991) \text { and linear } \\
\text { dep. on daily } \\
\text { minimum temp. }\end{array}$ & $\begin{array}{l}\text { Linear dep. on soil } \\
\text { water potential }\end{array}$ & $\begin{array}{l}\text { Hyperbolic dep. } \\
\text { on photon flux } \\
\text { density }\end{array}$ & Linear dep. on VPD & \multirow[t]{5}{*}{ None } \\
\hline & LPJ & $\begin{array}{l}\text { Function of a PFT- } \\
\text { specific minimum } \\
\text { canopy conductance, } \\
\text { the calculated opti- } \\
\text { mal photosynthetic } \\
\text { rate, and water stress } \\
\text { (Haxeltine \& Prentice, } \\
\text { 1996) }\end{array}$ & $\begin{array}{l}\text { through photosyn- } \\
\text { thesis }\end{array}$ & $\begin{array}{l}\text { Funct. of the act. } \\
\text { (supply-limited) } \\
\text { evapotransp. Rate. }\end{array}$ & $\begin{array}{l}\text { through photo- } \\
\text { synthesis }\end{array}$ & & \\
\hline & ORC & Ball et al. 1987 & & $\begin{array}{l}\text { No effect when soil } \\
\text { water above } 50 \% \\
\text { of field cap., lin- } \\
\text { ear decr. to wilting } \\
\text { point below }\end{array}$ & & $\begin{array}{l}\text { Linear response to } \\
\text { relative humidity }\end{array}$ & \\
\hline & JUL & $\begin{array}{l}\text { Cox et al. (1998) (in } \\
\text { particular, see figure 6) }\end{array}$ & $\begin{array}{l}\text { As above for photo- } \\
\text { synthesis }\end{array}$ & $\begin{array}{l}\text { As above for photo- } \\
\text { synthesis }\end{array}$ & $\begin{array}{l}\text { As above for } \\
\text { photo-synthesis }\end{array}$ & $\begin{array}{l}\text { Decreasing conduc- } \\
\text { tance for increasing } \\
\text { leaf humidity deficit } \\
\text { (see Cox et al 1998) }\end{array}$ & \\
\hline & PIX & $\begin{array}{l}\text { According to Ball et } \\
\text { al. } 1987 \text { tuned to leaf } \\
\text { chamber data, see Falge } \\
\text { et al. } 2003\end{array}$ & $\begin{array}{l}\text { According to Ball et } \\
\text { al. } 1987\end{array}$ & $\begin{array}{l}\text { Linear infl. dep. on } \\
\text { soil matrix potential } \\
\text { - adj. to site data } \\
\text { with site climate }\end{array}$ & $\begin{array}{l}\text { According to } \\
\text { Ball et al. } 1987\end{array}$ & $\begin{array}{l}\text { According to Ball et } \\
\text { al. } 1987\end{array}$ & \\
\hline
\end{tabular}


Table A3. Detailed description of the process autotrophic respiration for the process-models Biome-BGC (BGC), Lund-Potsdam-Jena managed Land (LPJ), ORCHIDEE (ORC), JULES (JUL) and PIXGRO (PIX).

\begin{tabular}{|c|c|c|c|c|c|c|c|}
\hline Process & Model & $\begin{array}{l}\text { Basic } \\
\text { Equations }\end{array}$ & $\begin{array}{l}\text { Response to tempera- } \\
\text { ture }\end{array}$ & $\begin{array}{l}\text { Response to soil } \\
\text { water }\end{array}$ & $\begin{array}{l}\text { Response to radia- } \\
\text { tion }\end{array}$ & $\begin{array}{l}\text { Response to air hu- } \\
\text { midity }\end{array}$ & $\begin{array}{l}\text { Response to nitro- } \\
\text { gen availability }\end{array}$ \\
\hline \multirow[t]{4}{*}{$\begin{array}{l}\text { Auto-trophic respi- } \\
\text { ration }\end{array}$} & BGC & $\begin{array}{l}\text { Maintenance resp. af- } \\
\text { ter Ryan (1991) } \\
\text { Growth resp. is linear } \\
\text { dep. on mass of new } \\
\text { plant tissue (Thorn- } \\
\text { ton, 1998) }\end{array}$ & $\begin{array}{l}\mathrm{Q}_{10} \quad \text { relationship, } \\
\mathrm{Q}_{10}=2\end{array}$ & None & None & None & $\begin{array}{l}\text { Linear dependence } \\
\text { on mass of nitrogen } \\
\text { in plant tissue }\end{array}$ \\
\hline & LPJ & $\begin{array}{l}\text { Maintenance resp.: } \\
\text { sum of leaf, sapwood, } \\
\text { and root respirations, } \\
\text { based on PFT-specific } \\
\text { respiration rates } \\
\text { (Ryan, 1991; Sprugel, } \\
\text { 1995) } \\
\text { Growth resp.: } 25 \% \text { of } \\
\text { the remainder GPP - } \\
\text { maint. resp. (Ryan, } \\
\text { 1991) }\end{array}$ & $\begin{array}{l}\text { Modified Arrhenius } \\
\text { equation (Lloyd \& } \\
\text { Taylor, 1994), consid- } \\
\text { ering either air or soil } \\
\text { temperature }\end{array}$ & & & & \\
\hline & ORC & $\begin{array}{l}\text { Maintenance resp. } \\
\text { (Ruimy et al., 96), } \\
30 \% \text { of alloc. biomass } \\
\text { for growth resp. }\end{array}$ & $\begin{array}{l}\text { Linear response, } \\
\text { Coefficients dep. on } \\
\text { carbon pool. } \\
\text { Cr(sapwood)= } \\
1.2 \mathrm{e}-4 \mathrm{~g} / \mathrm{g} / \text { day } \\
\mathrm{Cr}(\mathrm{leaf})= \\
2.3 \mathrm{e}-3 \mathrm{~g} / \mathrm{g} / \text { day }\end{array}$ & & & & \\
\hline & JUL & $\begin{array}{l}\text { Maintenance respira- } \\
\text { tion }(\mathrm{Cox}, 2001) \text {. } \\
25 \% \text { of allocated } \\
\text { biomass for growth } \\
\text { respiration }\end{array}$ & $\begin{array}{l}\text { Linear response, } \\
\text { Coefficients depend } \\
\text { on carbon pool (with } \\
\text { fixed C:N ratios). } \\
\text { Multiple of leaf } \\
\text { dark respiration with } \\
\mathrm{Q}_{10} \text { temperature } \\
\text { relationship }\end{array}$ & $\begin{array}{l}\text { None, other than } \\
\text { through moisture } \\
\text { controls on GPP. }\end{array}$ & & & \\
\hline $\begin{array}{l}\text { Canopy dark respi- } \\
\text { ration }\end{array}$ & PIX & $\begin{array}{l}\text { Enzyme activation } \\
\text { (see Falge et al. 2003; } \\
\text { Owen et al. 2007) } \\
\text { tuned to leaf chamber } \\
\text { data }\end{array}$ & $\begin{array}{l}\text { Exponential increase } \\
\text { with temperature }\end{array}$ & Not influenced & $\begin{array}{l}\text { Reduced with PFD } \\
\text { above } 50 \mu \mathrm{mol} \\
\mathrm{m}^{-2} \mathrm{~s}^{-1} \text { to } 50 \%\end{array}$ & None & \\
\hline
\end{tabular}


Table A4. Detailed description of the process heterotrophic respiration for the process-models Biome-BGC (BGC), Lund-Potsdam-Jena managed Land (LPJ), ORCHIDEE (ORC), JULES (JUL) and PIXGRO (PIX).

\begin{tabular}{|c|c|c|c|c|c|c|c|}
\hline Process & Model & $\begin{array}{l}\text { Basic } \\
\text { Equations }\end{array}$ & $\begin{array}{l}\text { Response to tem- } \\
\text { perature }\end{array}$ & $\begin{array}{l}\text { Response to soil } \\
\text { water }\end{array}$ & $\begin{array}{l}\text { Response to radia- } \\
\text { tion }\end{array}$ & $\begin{array}{l}\text { Response to air hu- } \\
\text { midity }\end{array}$ & $\begin{array}{l}\text { Response to nitro- } \\
\text { gen availability }\end{array}$ \\
\hline \multirow[t]{4}{*}{$\begin{array}{l}\text { Hetero-trophic res- } \\
\text { piration }\end{array}$} & BGC & $\begin{array}{l}\text { Soil pool specific de- } \\
\text { comp. rate constants } \\
\text { corrected by scalar dep. } \\
\text { on soil temp., moisture, } \\
\text { and nitrogen availabil- } \\
\text { ity (Thornton, 1998) }\end{array}$ & $\begin{array}{l}\text { Exponential dep. } \\
\text { on soil temp. } \\
\text { after Lloyd and } \\
\text { Taylor (1994), } \\
\text { minimum temp. is } \\
10^{\circ} \mathrm{C}\end{array}$ & $\begin{array}{l}\text { Log. dep. on soil } \\
\text { water pot. after } \\
\text { (Orchard and Cook, } \\
\text { 1983; Andren and } \\
\text { Paustian, 1987) }\end{array}$ & None & None & $\begin{array}{l}\text { Acc. to relationship } \\
\text { between nitrogen } \\
\text { demand and soil } \\
\text { nitrogen availability }\end{array}$ \\
\hline & LPJ & $\begin{array}{l}\text { Specific decomposition } \\
\text { rate for the labile pool } \\
\text { (litter), and the inter- } \\
\text { mediate \& slow pools } \\
\text { (SOM) }\end{array}$ & $\begin{array}{l}\text { Modified Arrhenius } \\
\text { rel. (Llyod \& Tay- } \\
\text { lor, 1994) cons. ei- } \\
\text { ther air or soil temp. }\end{array}$ & $\begin{array}{lr}\begin{array}{l}\text { Empirical } \\
\text { moisture }\end{array} & \text { soil } \\
\text { rela- } \\
\text { tionship } \\
\text { 1995) }\end{array}$ & & & \\
\hline & ORC & $\begin{array}{l}\text { Based on the CEN- } \\
\text { TURY model, (Parton } \\
\text { et al. 88) }\end{array}$ & $\begin{array}{l}\text { Q10 response to } \\
\text { soil temperature } \\
\text { temp. Q10=2 }\end{array}$ & $\begin{array}{l}\text { Hyperb. resp. to } \\
\text { soil water, } 1 \text { at field } \\
\text { cap. } 0.25 \text { at } 25 \% \\
\text { of field cap.. Const. } \\
0.25 \text { below }\end{array}$ & & & \\
\hline & JUL & Cox (2001) & $\begin{array}{l}\text { Q10 response to } \\
\text { soil temp. in top } \\
10 \mathrm{~cm}(\mathrm{q} 10=2)\end{array}$ & $\begin{array}{l}\text { Piecewise linear } \\
\text { based on McGuire } \\
\text { et al (1992), with } \\
\text { min. below wilt. } \\
\text { point, and opt. mid } \\
\text { way betw. wilt. and } \\
\text { sat. }\end{array}$ & & & \\
\hline $\begin{array}{l}\text { Ecosystem respira- } \\
\text { tion }\end{array}$ & PIX & $\begin{array}{l}\text { Acc. to modified Lloyd } \\
\text { and Taylor (1994) }\end{array}$ & $\begin{array}{l}\text { Exponential incr. } \\
\text { with temp. }\end{array}$ & $\begin{array}{l}\text { Linear decr. with } \\
\text { soil matrix pot. }\end{array}$ & None & None & \\
\hline
\end{tabular}


Acknowledgements. This study was funded through the CARBOEUROPE-Integrated Project "Assessment of the European Carbon Balance", contract number: GOCE-CT-2003-505572.

Edited by: T. R. Christensen

\section{References}

Adiku, S. G. K., Reichstein, M., Lohila, A., Dinh, N. Q., Aurela, M., Laurila, T., Lueers, J., and Tenhunen, J. D.: PIXGRO: A model for simulating the ecosystem $\mathrm{CO}_{2}$ exchange and growth of spring Barley, Ecological Modelling, 190, 260-276, 2006.

Andren, O. and Paustian, K.: Barley straw decomposition in the field - A comparison of models, Ecology, 68(5), 1150-1200, 1987.

Ball, J. T., Berry, J. A., and Woodrow I. E.: Conductance and its contribution to the control of photosynthesis under different environmental conditions, in: Progress in Photosynthesis Research, Vol. VI, edited by: Binggins I. J., Martin Nijhof, Dordrecht, 221224, 1987.

Ball, J. T. and Berry, J. A.: The C/C ratio: a basis for predicting stomatal control of photosyntheis, Carnegie Institute Washington Year Book, 81, 88-92, 1982.

Bondeau, A., Smith, P. C., Zaehle, S., Schaphoff, S., Lucht,W., Cramer, W., Gerten, D., Lotze-Campen, H., Müller, C., Reichstein, M., Smith, B.: Modelling the role of agriculture for the 20th century global terrestrial carbon balance, Glob. Change Biol., 13 (3) 679-706, 2007.

Botta, A., Viovy, N., Ciais, P., and Friedlingstein, P.: A global prognostic scheme of leaf onset using satellite data, Glob. Change Biol., 6, 709-726, 2000.

Chen, Y., Churkina, G., Heimann, M.: A comparison of regional climate variations between various data sources. Technical reports - Max-Planck-Institut fr Biogeochemie, 8, pp36, 2007.

Churkina, G., Tenhunen, J., Thornton, P. E., Elbers, J. A., Erhard, M., Falge, E., Gruenwald, T., Kowalski, A. S., Rannik, U., and Sprinz, D. E.: Analyzing the ecosystem carbon dynamics of four European coniferous forests using a biogeochemistry model, ECOSYSTEMS, 6, 168-184, 2003.

Churkina, G. and Running, S.W.: Investigating the balance between timber harvest and productivity of the global coniferous forests under global change, Climatic Change, 47, 167-191, 2000.

Churkina, G. and Running, S. W.: Contrasting climatic controls on the estimated productivity of global terrestrial biomes, Ecosystems, 1, 206-215, 1998.

Ciais, P., Reichstein, M., Viovy, N. Granier, A., Ogee, J., Allard, V., Aubinet, M., Buchmann, N., Bernhofer, C., Carrara, A., Chevallier, F., De Noblet, N., Friend, A. D., Friedlingstein, P., Grünwald, T., Heinesch, B., Keronen, P., Knohl, A., Krinner, G., Loustau, D., Manca, G., Matteucci, G., Miglietta, F., Ourcival, J. M., Papale, D., Pilegaard, K., Rambal, S., Seufert, G., Sousanna, J. F, Sanz, M. J., Schulze, E. D., Vesala, T., and Valentini, $\mathrm{R}$.. Europe-wide reduction in primary productivity caused by the heat and drought in 2003, Nature, 437, 529-533, 2005.

Cienciala, E., Running, S. W., Lindroth, A., Grelle, A., and Ryan, M. G.: Analysis of carbon and water fluxes from the NOPEX boreal forest: comparison of measurements with Forest-BGC simulations, J. Hydrol., 212-213, 62-78, 1998.
Cosby, B. J., Hornberger, G. M., Clapp, R. B., and Ginn, T. R.: A statistical exploration of the relationships of soil moisture characteristics to the physical properties of soils, Water Resources Res., 20, 682-690, 1984.

Collatz, G. J., Ribas-Carbo, M., and Berry, J. A.: A coupled photosynthesis- stomatal conductance model for leaves of C4 plants, Australian J. Plant Physiol., 19, 519-538, 1992.

Collatz, G. J., Ball, J. T., Grivet, C., and Berry, J. A.: Physiological and environmental regulation of stomatal conductance, photosynthesis and transpiration: A model that includes a laminar boundary layer, Agriculture and Forest Meteorology, 54, 107136,1991

Cox, P. M.: Description of the TRIFFID Dynamic Global Vegetation Model, Hadley Centre Technical Note 24, Hadley Centre, Met Office, Exeter, UK, 2001.

Cox, P. M., Betts, R. A., Jones, C. D., Spall, S. A., and Totterdell, I. J.: Acceleration of global warming due to carbon-cycle feedbacks in a coupled climate model, Nature, 408, $184-187,2000$.

Cox, P. M., Betts, R. A., Bunton, C. B., Essery, R. L. H., Rowntree, P. R., and Smith, J.: The impact of new land surface physics on the GCM simulation of climate and climate sensitivity, Clim. Dynam., 15, 183-203, 1999.

Cox, P. M., Huntingford, C., and Harding, R. J.: A canopy conductance and photo-synthesis model for use in a GCM land surface scheme, J. Hydrol., 212-213, 79-94, 1998.

De Pury, D. G. G. and Farquhar, G. D.: Simple scaling of photosynthesis from leaves to canopies without the errors of big-leaf models, Plant, Cell and Enviroment, 20(5), 537-557, 1997.

Ding, Q. and Wang, B.: Circumglobal teleconnection in the northern hemisphere summer, J. Climate, 18, 3483-3505, 2005.

Ducoudre, N., Laval, K., and Perrier, D.: SECHIBA, a new set of parameterizations of the hydrologic exchanges at the landatmosphere interface within the LMD atmospheric circulation model, J. Climate, 6, 248-273, 1993.

Essery, R. L. H., Best, M. J., Betts, R. A., Cox, P. M., and Taylor, C. M.: Explicit representation of subgrid heterogeneity in a GCM land-surface scheme, J. Hydrometeorol., 43, 530-543, 2003.

Etheridge, D. M., Steele, L. P., Langenfelds, R. L., Francey, R. J., Barnola J.-M., and Morgan, V. I.: Natural and anthropogenic changes in atmospheric $\mathrm{CO}_{2}$ over the last 1000 years from air in Antarctic ice and firn, J. Geophys. Res., 101, 4115-4128, 1996.

Farquahar, G., von Caemmerer, S., and Berry, J.: A biochemical model of photosynthetic $\mathrm{CO}_{2}$ assimilation in leaves of $\mathrm{C}_{3}$ species, Planta, 149, 78-80, 1980.

Food and Agriculture Organization of the United Nations, FAOSTAT, June 2006, (http://faostat.fao.org/site/422/default.aspx).

Feser, F., Weisse, R., and von Storch, H.: Multi-decadal Atmospheric Modeling for Europe Yields Multi-purpose Data, EOS Transactions, 82, 305-310, 2001.

Fink, A. H., Brücher, T., Krüger, A., Leckebusch, G. C., Pinto, J. G., and Ulbrich, U.: The 2003 European heatwaves and drought - synoptic discussions and impacts, Weather, 59(8), 209-216, 2004.

Friend, A. D., Shugart, H. H., and Running, S. W.: A physiologybased model of forest dynamics, Ecology, 74, 797-797, 1993.

Freibauer, A.: Regionalized inventory of biogenic greenhouse gas emissions from European agriculture, European Journal of Agronomy, 19, 135-160, 2003.

Friedlingstein, P., Joel, G., Field, C. B., and Fung, I.: Towards 
an allocation scheme for global terrestrial carbon models, Glob. Change Biol., 5, 755, 1998.

Foley, J. A.: An equilibrium model of the terrestrial carbon budget, Tellus, 47B, 310-319, 1995.

Galloway, J. N., Dentner, F. J., Capone, D. G., Boyer, E. W., Howarth, R. W., Seitzinger, S. P., Asner, G. P., Cleveland, C. C., Green, P. A., Holland, E. A., Karl, D. M., Michaelis, A. F., Porter, J. H., Townsend, A. R., and Vörsömarty, C. J.: Nitrogen cycles: past, present and future, Biogeochemistry, 70, 153-226, 2004.

Gregory, D. and Smith, R. N. B.: Canopy, surface and soil hydrology. Unified Model documentation paper 25, Meteorological Offce, London Rd, Bracknell, Berkshire, RG12 2SY, 1990.

Guo, Z. and Dirmeyer, P. A.: Evaluation of the Second Global Soil Wetness Project soil moisture simulations: 1. Intermodel comparison, J. Geophys. Res., 111, D22S02, doi:10.1029/2006JD007233.u, 2006.

Harrison, R. G., Jones, C. D., and Hughes, J. K.: Competing roles of rising $\mathrm{CO}_{2}$ and climate change in the contemporary European carbon balance, Biogeosciences, 5, 1-10. 2008.

Haxeltine, A. and Prentice, I. C.: BIOME3:an equilibrium terrestrial biosphere model based on ecophysiological constraints, resource availability and competition among plant functional types, Global Biogeochem. Cy., 10, 693-710, 1996.

Holland, E. A., Dentner, F. J., Braswell, B. H., and Sulzmann, J. M.: Contemporary and pre-industrial global reactive nitrogen budgets, Biogeochemistry, 46, 7-43, 1999.

Intergovernmental Panel of Climate Change (IPCC): Climate change 2007: Physical science basis. Summary for Policymakers, IPCC, Genf, Switzerland, http://www.ipcc.ch/SPM2feb07. pdf, 2007.

Jacob, D. and Podzun, R.: Sensitivity Studies with the Regional Climate Model REMO, Meteorol. Atmos. Phys., 63, 119-129, 1997.

Jacobs, C.: Direct impact of atmospheric $\mathrm{CO}_{2}$ enrichment on regional transpiration, $\mathrm{PhD}$ thesis, Wageningen Agricultural University, 1994.

Johns, T. C., Durman, C. F., Banks, H. T., Roberts, M. J., McLaren, A. J., Ridley, J. K., Senior, C. A., Williams, K. D., Jones, A., Rickard, G. J., Cusack, S., Ingram, I. M., Crucifix, M., Sexton, M. H., Joshi, M. M., Dong, B. W., Spencer, H., Hill, R. S. R., Gregory, J. M., Keen, A. B., Pardaens, A. K., Lowe, J. A., BodasSalcedo, A., Stark, S., and Searl, Y.: . The new Hadley Centre climate model HadGEM1: Evaluation of coupled simulations, J. Climate, 19(7), 1327-1353, 2006.

Jolly, W. M., Dobberlin, M., Zimmermann, N. E., and Reichstein, M.: Divergent vegetation growth responses to the 2003 heat wave in the Swiss Alps, Geophys. Res. Lett., 32, L18409, doi:10.1029/2005GL023252, 2005.

Jones, C. D. and Cox, P. M.: On the significance of atmospheric $\mathrm{CO}_{2}$ growth-rate anomalies in 2002-2003, Geophys. Res. Lett. 32, L14816, doi:10,1029/2005GL023027, 2005.

Jung, M., Henkel, K., Herold, M., and Churkina, G.: Exploiting synergies of global land cover products for carbon cycle modeling, Remote Sensing of Environment, 101, 534-553, 2006.

Kalnay, E., Kanamitsu, M., Kistler, R., Collins, W., Deaven, D., Gandin, L., Iredell, M., Saha, S., White, G., Woollen, J., Zhu, Y., Chelliah, M., Ebisuzaki, W., Higgins, W., Janowiak, J., Mo, K.C., Ropelewski, C., Wang ,J., Leetmaa, A., Reynolds, R.,
Jenne, R., and Joseph, D.: The NCEP/NCAR reanalysis project, Bull. Am. Meteor. Soc., 77, 437-471, 1996.

Keeling, C. D., and Whorf, T. P.: Atmospheric $\mathrm{CO}_{2}$ records from sites in the SIO air sampling network, In Trends: A Compendium of Data on Global Change. Carbon Dioxide Information Analysis Center, Oak Ridge National Laboratory, U.S. Department of Energy, Oak Ridge, Tenn., USA, 2005.

Lloyd, J. and Taylor, J. A.: On the temperature dependence of soil respiration, Functional Ecology, 8, 315-323, 1994.

Koch, W. and Feser, F.: Relationship between SAR derived wind vectors and wind at ten meters height represented by a mesoscale model, Mon. Weather Rev., 134(5), 1505-1517, 2006.

Korner, C., Perterer, J., Altrichter, C., Meusburger, A., Slovik, S., and Zoschg, M.: A simple empirical model to estimate annual dry deposition of atmospheric pollutants in needles of spruce and pine, Allgemeine Forst und Jagdzeitung, 166, 1-9, 1995.

Krinner, G., Viovy, N., de Noblet-Ducoudre, N., Ogee, J., Polcher, J., Friedlingstein, P., Ciais, P., Sitch, S., and Prentice, I. C.: A dynamic global vegetation model for studies of the coupled atmosphere-biosphere system, Global Biogeochem. Cy., 19, GB1015, doi:10.1029/2003GB002199, 2005.

Lucero, O. A. and Rodriguez, N. C.: Spatial organization in Europe of decadal and interdecadal fluctuations in annual rainfall, Int. J. Climatol., 22, 805-820, 2002.

Lucht, W., Schaaf C. B., and Strahler, A. H.: An Algorithm for the retrieval of albedo from space using semiempirical BRDF models, IEEE Trans. Geosci. Remote Sens., 38, 977-998, 2000.

McGuire, A., Melillo, J., Joyce, L., Kicklighter, D., Grace, A., Ill, B. M., and Vorosmarty, C.: Interactions between carbon and nitrogen dynamics in estimating net primary productivity for potential vegetation in North America, Global Biogeochem. Cy., 6, 101-124, 1992.

Monteith, J. L.: Accomodation between transpiring vegetation and the convective boundary level, J. Hydrol., 166, 251-263, 1995.

Monteith, J. L.: Evaporation and environment, Symposium of the society of experimental biology, 19, 205-234, 1965.

Neilson, R. P.: Vegetation redistribution: a possible biosphere source of $\mathrm{CO}_{2}$ during climate change, Water, Air and Aoil Pollution, 70, 659-673, 1993.

Nemani, R. R., Keeling, C. D., Hashimoto, H., Jolly, W. M., Piper, S. C., Tucker, C. J., Myneni, R. B., and Running, S. W.: Climatedriven increases in global terrestrial net primary production from 1982 to 1999, Science, 300(5625), 1560-1563, 2003.

Orchard, V. A. and Cook, F. J.: Relationship between soil respiration and soil moisture, Soil Biology and Biochemistry, 15(4), 447-453, 1983.

Owen, K. E., Tenhunen, J., Reichstein, M., Wang, Q., Falge, E., Geyer, R., Xiao, X., Stoy, P., Ammann, C., Arain, A., Aubinet, M., Auerla, M., Bernhofer, C., Chojnicki, B., Granier, A., Gruenwald, T., Hadley, J., Heinesch, B., Hollinger, D., Knohl, A., Kutsch, W., Lohila, A., Meyers, T., Moors, E., Moureaux, C., Pilegaard, K., Saigusa, N., Verma, S., Vesala, T., and Vogel, C.: Linking flux network measurements to continental scale simulations: ecosystem $\mathrm{CO}_{2}$ exchange capacity under non-waterstressed conditions, Glob. Change Biol., 13(4), 734-760, doi: 10.1111/j.1365-2486.2007.01326.x, 2007.

Papale, D., Reichstein, M., Aubinet, M., Canfora, E., Bernhofer, C., Kutsch, W., Longdoz, B., Rambal, S., Valentini, R., Vesala, T., and Yakir, D.: Towards a standardized processing of Net Ecosys- 
tem Exchange measured with eddy covariance technique: algorithms and uncertainty estimation, Biogeosciences, 3, 571-583, 2006 , http://www.biogeosciences.net/3/571/2006/.

Papale, D. and Valentini, R.: A new assessment of European forests carbon exchanges by eddy fluxes and artificial neural network spatialization, Glob. Change Biol., 9, 525-535, 2003.

Reichstein, M., Ciais, P., Papale, D., Valentini, R., Running, S. W., Viovy, N., Cramer, W., Granier, A., Ogee, J., Allard, V., Aubinet, M., Bernhofer, C., Buchmann, N., Carrara, A., Grünwlad, T., Heimann, M., Heinesch, B., Knohl, A., Kutsch, W., Loustau, D., Manca, G., Matteucci, G., Miglietta, F., Ourcival, J. M., Pilegaard, K., Pumpanen, J., Rambal, S., Schaphoff, S., Seuffert, G., Sousanna, J. F., Sanz, M. J., Vesala, T., and Zhao, M.: Reduction of ecosystem productivity and respiration during the European summer 2003 climate anomaly: a joint flux tower, remote sensing and modelling analysis, Glob. Change Biol., 12, 1-18, doi:10.1111/j.1365-2486.2006.01224.x, 2006.

Reichstein, M., Falge, E., Baldocchi, D., Papale, D., Aubinet, M., Bebigier, P., Bernhofer, C., Buchmann, N., Gilmanov, T., Granier, A., Grunwald, T., Havrankova, K., Ilvesniemi, H., Jonous, D., Knohl, A., Laurila, T., Lohila, A., Loustau, D., Matteucci, G., Meyers, T., Miglietta, F., Ourcival, J. M., Pumpanen, J., Rambal, S., Rotenberg, E., Sanz, M., Tenhunen, J., Seuffert, G., Vaccari, F., Vesala, T., Yakir, D., and Valentini, R.: On the separation of net ecosystem exchange into assimilation and ecosystem respiration: review and improved algorithm, Glob. Change Biol., 11, 1424-1439, 2005.

Reichstein, M., Valentini, R., Running, S. W., and Tenhunen, J.: Improving remote-sensing based GPP estimates (MODIS-MOD17) through inverse parameter estimation with CARBOEUROPE eddy covariance flux data, EGU meeting Nice 2004, Geophys. Res. Abstracts, 6:, 01388, 2004.

Reichtein, M., Rey, A., Freibauer, A., Tenhunen, J., Valentini, R., Banza, J., Casals, P., Cheng, Y. F., Grunzweig, J. M., Irvine, J., Joffre, R., Law, B. E., Loustau, D., Miglietta, F., Oechel, W., Ourcival, J. M., Pereira, J. S., Peresotti, A., Ponti, F., Oi, Y., Rambal, S., Rayment, M., Romanya, J., Rossi, F., Tedeschi, V., Tirone, G., Xu, M., and Yakir, D.: Modelling temporal and largescale spatial variability of soil respiration from soil water availability, temperature and vegetation productivity indices, Global Biogeochem. Cy., 17(4), 15/1-15/15, 2003a.

Reichstein, M., Tenhunen, J., Ourcival, J.-M., Rambal, S., Maglietta, F., Peressotti, A., Pecchiari, M., Tirone, G., and Valentini, R.: Inverse modeling of seasonal drought effects on canopy $\mathrm{CO}_{2} / \mathrm{H}_{2} \mathrm{O}$ exchange in three Mediterranean Ecosystems, J. Geophys. Res., 108(D23), 4726, 4716/4721-4716/4716, 2003 b.

Reichstein, M.: Drought effects on carbon and water exchange in three Mediterranean ecosystems, Ph.D. Dissertation, University of Bayreuth, Germany, BITOEK Pub. Bayreuth, Germany, 150 pp., 2001.

Richards, L.: Capilliary conduction of liquids through porous mediums, Physics, 1, 318-333, 1931.

Running, S. W. and Gower, S. T.: Forest-BGC, a general model of forest ecosystem processes for regional applications. 2, Dynamic carbon allocation and nitrogen budgets, Tree Physiology, 9, 147160, 1991.

Running, S. W., Nemani, R. R., Heinsch, F. A., Zhao, M., Reeves, M., and Hashimoto, H.: A continuous satellite-derived measure of global terrestrial primary production, Bioscience, 54(6), 547560, 2004.

Saxton, K. E., Rawls, W. J., Romberger, J. S., and Papendick, R. I.: Estimating generalized soil-water characteristics from texture, Soil science society of America, 50(4), 1031-1036, 1986.

Scardi, M.: Advances in neural network modeling of phytoplankton primary production, Ecological modeling Ecological Modelling, 146, 33-45, 2001.

Schaaf, C. B., Gao, F., Strahler, A. H., Lucht, W., Li, X. W., Tsang, T., Strugnell, N. C., Zhang, X. Y., Jin, Y. F., Muller, J. P., Lewis, P., Barnsley, M., Hobson, P., Disney, M., Roberts, G., Dunderdale, M., Doll, C., d'Entremont, R. P., Hu, B. X., Liang, S. L., Privette, J. L., and Roy, D.: First Operational BRDF, Albedo and Nadir Reflectance Products from MODIS, Remote Sens.Environ., 83(1-2), 135-148, 2002.

Schimel, D. S., Churkina, G., Braswell, R. H., and Trembath, J.: Remembrance of weather past: Ecosystem response to climate variability, in: A history of atmospheric $\mathrm{CO}_{2}$ and its effects on plants, animals, and ecosystems, edited by: J. R. Ehleringer, T. E. Cerling, and M. D. Dearing, Springer-Verlag, Berlin, 2005.

Schindler, D., Türk, M., and Mayer, $\mathrm{H}$.: $\mathrm{CO}_{2}$ fluxes of a Scots pine forest growing in the warm and dry southern upper Rhine plain, SW Germany, European Journal of Forest Research, 125, 201212, 2006.

Sitch, S., Smith, B., Prentice, I. C., Arneth, A., Bondeau, A., Cramer, W., Kaplan, J., Levis, S., Lucht, W., Sykes, M., Thonicke, K., and Venevski, S.: Evaluation of ecosystem dynamics, plant geography and terrestrial carbon cycling in the LPJ dynamic vegetation model, Glob. Change Biol., 9, 161-185, 2003.

Sprugel, D. G., Ryan, M. G., Brooks, J. R., et al.: Respiration from the organ level to the stand, In: Resource Physiology of Conifers: Acquisition, Allocation and Utilization, edited by: Smith, W. K. and Hinckley, T.M., Academic Press, San Diego, 25-299, 1995.

Storch, von H., Langenberg, H., and Feser, F.: A Spectral Nudging Technique for Dynamical Downscaling Purposes, Mon. Weather Rev., 128, 3664-3673, 2000.

Tenhunen, J., Geyer, R., Banza, J., Besson, C., Carreiras, J., Dinh, N. Q., Herd, A., Mirzae, H., Otieno, D., Owen, K., Pereira, J. S., Reichstein, M., Ribeiro, N., Schmidt, M., and Xiao, X.: Assessing ecology, vulnerability and ecosystem services of Mediterranean oak woodlands, in: Science and Practice of Ecological Restoration, edited by: Aronson, J., Pereira, J. S., and Pausas, J., Island Press, Washington, D.C., in press, 2007.

Thornton, P. E., Law, B. E., Gholz, H. L., Clark, K. L., Falge, E., Ellsworth, D. E., Goldstein, A. H., Monson, R. H., Hollinger, D. Y., Falk, M., and Falk, J. P.: Modelling and measuring the effects of disturbance history on carbon and water budgets in evergreen needleleaf forests, Agricultural and forest meteorology, 113, 185-222, 2002.

Trigo, R. M., Garcia-Herrera, R., Diaz, J., Trigo, I. F., and Valente, M. A.: How exceptional was the early August 2003 heatwave in France, Geophys. Res. Lett., 32, L10701, doi:10.1029/2005GL022410, 2005.

Verburg, P. J., Laresen, J., Johnson, D. W., Schorran, D. E., and Arnone, III. J. A.: Impacts of an anomalously year on soil $\mathrm{CO}_{2}$ efflux in experimentally manipulated tallgrass prairie ecosystems, Glob. Change Biol., 11, 1720-1732, doi:10.1111(j.13652486.2005.01032.x, 2005.

Vetter, M., Wirth, C., Bottcher, H., Churkina, G., Schulze, E. 
D., Wutzler, T., and Weber, G.: Partitioning direct and indirect human-induced effects on carbon sequestration of managed coniferous forests using model simulations and forest inventories, Glob. Change Biol., 11, 810-827, 2005.

Viovy, N.: Interannuality and $\mathrm{CO}_{2}$ sensitivity of the SECHIBABGC coupled SVAT-BGC model, Phys. Chem. Earth, 21, 489-4 97, 1996.

Woodrow, I. E. and Berry, J. A.: Enzymatic regulation of photosynthetic $\mathrm{CO}_{2}$ fixation in $\mathrm{C} 3$ plants, Annual Review of Plant Physiology and Plant Molecular Biology, 39, 533-594, 1988.

Zaehle, S., Bondeau, A., Carter, T., Cramer, W., Erhard, M., Prentice, I. C., Reginster, I., Rounsevell, M. D. A., Sitch, S., Smith, B., Smith, P. C., Sykes, M.: Projected changes in terrestrial carbon storage in Europe under climate and land-use change, 1990-2100, Ecosystems 10(3), 380-401, doi:10.1007/s10021007-9028-9, 2007.
Zeng, N., Quian, H., Rödenbeck, C., and Heimann, M.: Impact of 1998-2002 midlatitude drought and warming on terrestrial ecosystem and the global carbon cycle, Geophys. Res. Lett., 32, L22709, doi:10.1029/2005GL024607, 2005.

Zhang, X., Friedl, M. A., Schaaf, C. B., and Strahler, A. H.: Climate controls on vegetation phenological patterns in northern mid- and high latitudes inferred from MODIS data, Glob. Change Biol., 10, 1133-1145, 2004.

Zveryaev, I. I.: Seasonality in precipitation variability over Europe, J. Geophys. Res., 109, D05103, doi:10.1029/2003JD003668, 2004. 